\title{
Delayed Expected Loss Recognition and the Risk Profile of Banks
}

\author{
ROBERT M. BUSHMAN* AND CHRISTOPHER D. WILLIAMS
}

Received 27 July 2012; accepted 9 February 2015

\section{ABSTRACT}

This paper investigates the extent to which delayed expected loan loss recognition $(D E L R)$ is associated with greater vulnerability of banks to three distinct dimensions of risk: (1) stock market liquidity risk, (2) downside tail risk of individual banks, and (3) codependence of downside tail risk among banks. We hypothesize that $D E L R$ increases vulnerability to downside risk by creating expected loss overhangs that threaten future capital adequacy and by degrading bank transparency, which increases financing frictions and opportunities for risk-shifting. We find that DELR is associated with higher correlations between bank-level illiquidity and both aggregate banking sector illiquidity and market returns (i.e., higher liquidity risks) during recessions, suggesting that high DELR banks as a group may simultaneously face elevated financing frictions and enhanced opportunities for risk-shifting behavior in crisis periods. With respect to downside risk, we find that during recessions DELR is associated with significantly higher risk of individual banks suffering severe drops in their equity values, where this association is magnified for banks with low capital levels. Consistent with increased systemic risk, we

\footnotetext{
* Kenan-Flagler Business School, University of North Carolina-Chapel Hill; ${ }^{\dagger}$ Ross School of Business, University of Michigan.

Accepted by Philip Berger. We thank Ryan Ball, Mary Barth, Anne Beatty, Christian Leuz, Mitch Petersen (discussant), an anonymous referee, and workshop participants at Harvard, Seoul National University, University of Michigan, University of Minnesota Empirical Conference, the JAR/NY Fed Pre-Conference, JAR/NY Fed Conference, Rice University, and the Utah Winter Accounting Conference for helpful comments. Bushman thanks KenanFlagler Business School, University of North Carolina at Chapel Hill, and Williams thanks the PriceWaterhouseCoopers-Norm Auerbach Faculty Fellowship for financial support. We also thank Tianshu Qu for valuable RA assistance.
} 
find that $D E L R$ is associated with significantly higher codependence between downside risk of individual banks and downside risk of the banking sector. We theorize that downside risk vulnerability at the individual bank level can translate into systemic risk by virtue of DELR creating a common source of risk vulnerability across high $D E L R$ banks simultaneously, which leads to risk codependence among banks and systemic effects from banks acting as part of a herd.

JEL codes: G20; G21; M40; M41

Keywords: bank; transparency; loan loss provisions; delayed loss recognition; risk; systemic risk

\section{Introduction}

Banks take on risks that are opaque and difficult to verify. Of particular concern to bank regulators is excessive risk-taking by individual banks and systemic risk, which requires a focus not on the risk of individual banks, but on an individual bank's contribution to the risk of the financial system as a whole (e.g., Brunnermeier et al. [2009], Acharya et al. [2010], Hanson, Kashyap, and Stein [2011], Bisias et al. [2012]). An important unresolved issue is the extent to which bank transparency plays a role in mitigating or exacerbating such risk concerns. We define bank transparency as the availability of bank-specific information to those outside of the bank, which includes depositors, investors, borrowers, counterparties, regulators, policy makers, and competitors. ${ }^{1}$ A key source of bank transparency is publicly disclosed financial reports, which provide bank-specific information to investors and regulators seeking to understand a bank's fundamentals in order to guide investment decisions, discipline risk-taking, and enhance stability. Accounting policy choices can therefore potentially affect bank risk by impacting bank transparency. In addition to this transparency role, accounting policy can affect bank stability through its influence over the accounting numbers as quantitative inputs into numerical calculations of regulatory covenant measures such as capital ratios and leverage ratios that banks must continually maintain (e.g., Beatty and Liao [2011, 2014]).

In this paper, we investigate relations between banks' accounting policy choices and both individual bank risk and risk codependence among banks. We capture cross-bank variation in accounting policy choices by exploiting differences in the discretionary application of loan loss accounting rules across U.S. commercial banks to estimate the extent to which individual banks delay expected loan loss recognition in current provisions

\footnotetext{
${ }^{1}$ Transparency is the joint output of a multifaceted system whose component parts collectively produce, gather, validate, and disseminate information to participants outside the firm. Components include audited, publicly available accounting information, information intermediaries such as financial analysts, credit rating agencies and the media, regulatory reports (including stress test disclosures), banks' voluntary disclosures, and information transmitted by securities prices (Bushman and Smith [2003], Bushman, Piotroski, and Smith [2004]).
} 
$(D E L R)$. We then use a difference in difference design to investigate the extent to which DELR is associated with greater vulnerability of banks to three distinct dimensions of risk during economic downturns: (1) liquidity risk, which reflects how closely bank-level stock market illiquidity co-moves with aggregate banking sector illiquidity and stock returns; (2) downside tail risk of individual banks; and (3) codependence of downside tail risk among banks (i.e., system-wide risk).

Reductions in transparency can induce greater investor uncertainty about banks' intrinsic value, weaken market discipline over risk-taking behavior, and mask banks' efforts to suppress negative information that will be revealed in future periods. Accounting policy choices can plausibly impact bank transparency. We hypothesize that $D E L R$ is a manifestation of opportunistic loan provisioning behavior, which results in reduced bank transparency. To examine this hypothesis, we build on an extensive literature linking transparency to stock market illiquidity and liquidity risk (e.g., Amihud, Mendelson, and Pedersen [2005]). Liquidity risk reflects how closely bank-level stock market illiquidity co-moves with aggregate banking sector illiquidity and stock returns. Brunnermeier and Pedersen [2009] and Vayanos [2004] show that liquidity can dry up in crises when liquidity providers flee from assets with high levels of uncertainty about fundamental value. Brunnermeier and Pedersen [2009] argue that systematic shocks to the funding of liquidity providers can generate co-movement in liquidity across assets, particularly for stocks with greater uncertainty about intrinsic value. Further, Lang and Maffett [2011] empirically document that nonfinancial firms with lower transparency suffer greater increases in liquidity risk during crisis periods. Thus, to the extent that DELR reflects bank transparency, we expect higher DELR to be associated with higher bank illiquidity and liquidity risk, and that these associations will be stronger during crisis periods. Consistent with our hypothesis, we find that DELR is associated with higher stock market illiquidity and a higher correlation between bank-level illiquidity and aggregate banking sector illiquidity and returns during recessions. ${ }^{2}$ While stock illiquidity generally increases during economic recessions (Naes, Skjeltorp, and Arne Ødegaard [2011]), our results show that recessionary increases in illiquidity and liquidity risk are more severe for banks with higher levels of $D E L R{ }^{3}$ This has important implications for bank risk and stability.

First, illiquidity levels and liquidity risks associated with higher DELR increase equity financing costs, which can impede access to new equity

\footnotetext{
${ }^{2}$ While we show a relation between $D E L R$ and equity financing frictions, $D E L R$-driven opacity may also negatively impact access to credit funding and the terms demanded by creditors to supply such funding (e.g., Kashyap and Stein [1995, 2000], Ratnovski [2013]). This is an important avenue for future research.

${ }^{3}$ Our within banking sector analysis of DELR and illiquidity complements Flannery, Kwan, and Nimalendran [2013] across industry analysis showing that crises raise the adverse selection costs of trading bank shares relative to nonbank control firms.
} 
financing needed to replenish capital depleted by recessionary losses. ${ }^{4}$ In this regard, our illiquidity results extend and complement Beatty and Liao [2011], who raise the possibility that DELR may increase equity financing frictions without specifying how and why this might occur. ${ }^{5}$ By establishing a formal connection between DELR and transparency, we also complement Bushman and Williams [2012], who find that higher DELR is associated with more pronounced risk-shifting by banks, consistent with diminished transparency inhibiting monitoring by outsiders. Our liquidity risk results also have implications for systemic risk. Increased co-movement between bank-level illiquidity and banking sector illiquidity and returns suggests that high DELR banks as a group will simultaneously face elevated financing frictions when the banking sector is experiencing distress that impedes the group's access to new capital infusions. Further, DELR-induced reductions in transparency can dampen discipline of risk-taking for high DELR banks and result in these banks as a group exploiting opacity to engage in riskshifting behavior during crisis periods.

While our illiquidity analyses suggest that DELR degrades bank transparency, loan loss provisioning policies also directly affect reported capital. ${ }^{6}$ When a bank delays recognition of expected losses, it creates an overhang of unrecognized expected losses that carry forward to the future. Loss overhangs can increase capital inadequacy concerns during crises by compromising the ability of loan loss reserves to cover both unexpected recessionary loan losses and loss overhangs from previous periods. Thus DELR can negatively impact capital levels during a crisis while at the same time inhibiting banks' ability to replenish capital by increasing financing frictions via reduced transparency. This can create capital inadequacy concerns that increase the vulnerability to severe downside risk of individual banks and of the banking system as a whole. Such increases in downside risk vulnerability can derive from banks' reactions to capital inadequacy concerns as well as from actions by other players such as inter-bank lenders, other short-term creditors, and regulators responding to heightened concerns about bank insolvency.

\footnotetext{
${ }^{4}$ Acharya and Petersen [2005] decompose the CAPM beta to show that cost of capital is a function of illiquidity levels and liquidity risk. See also Pástor and Stambaugh [2003] and Lou and Sadka [2011].

${ }^{5}$ Beatty and Liao [2011] show that higher DELR banks exhibit smaller increases in book equity during economic downturns. They suggest two possible drivers of this result: (1) the cost of raising equity is higher during recessions and so low DELR banks raise more equity in good times to compensate for their higher provisions, and (2) the cost of raising equity during recessions is relatively higher for high DELR banks. We provide evidence consistent with this latter conjecture and isolate opacity-driven illiquidity (risk) as a specific mechanism through which DELR operates to increase financing frictions.

${ }^{6}$ It is also possible that banks set target capital levels above regulatory requirements in order to maintain a specific standing in credit markets (e.g., Berger et al. [2008]). To the extent that target capital levels are set based on reported accounting capital, DELR can still have a role in exacerbating downside risk through its effect on bank capital.
} 
Specifically, negative consequences of capital inadequacy include reduced bank lending (e.g., Bernanke and Lown [1991], Bolton and Freixas [2006], Beatty and Liao [2011]), deleveraging via asset sales potentially at fire sale prices (e.g., Hanson, Kashyap, and Stein [2011]), increased riskshifting incentives (e.g., Mehran, Acharya, and Thakor [2013]), decreased probability of survival, competitive position and market share (e.g., Berger and Bouwman [2013]), and increased borrowing costs and decreased availability of credit (e.g., Afonso and Schoar [2011], Kashyap and Stein [1995], [2000], Ratnovski [2013]). ${ }^{7}$ We do not attempt to differentiate such negative consequences individually, but instead consider the overall effect of $D E L R$ on downside risk from all sources collectively as reflected in the distributions over changes in market values of a bank's equity and assets.

Following Adrian and Brunnermeier [2011], we estimate conditional, time-varying distributions over future equity returns, and examine whether $D E L R$ affects the likelihood of severe negative outcomes. Using quantile regression, we estimate downside risk at a point in time as the value-at-risk ( VaR) at the $1 \%$ quantile. $^{8}$ VaR represents a cutoff value in the lower left tail of the distribution indicating that a bank or the banking system will experience negative equity returns over the upcoming period of VaR or more extreme with $1 \%$ probability. A more negative VaR indicates greater downside tail risk as it implies more probability weight over extreme negative outcomes. We estimate VaR for individual banks and the banking system as a whole.

We first examine the relation between $D E L R$ and $V a R$ for individual banks, finding that higher $D E L R$ is associated with significantly higher risk of severe drops in equity values during economic downturns. These individual bank results bear a relation with research showing that earnings management is associated with equity crash risk (e.g., Hutton, Marcus, and Tehranian [2009], Cohen et al. [2014]). These papers build on the idea that, if firms serially hide bad news, future release of accumulated buildups of negative information can cause stock price to crash (Jin and Myers [2006]). Our paper differs from this literature in several fundamental respects. First, we examine tail risk with respect to the ex ante distribution over equity returns, where the crash risk literature focuses on ex post return realizations. Second, the previous literature appeals to the theory of Jin and Myers [2006] but does not empirically specify the precise accounting policies driving buildups of negative information, while we exploit the

\footnotetext{
${ }^{7}$ In regard to capital-induced reductions in bank lending (i.e., a "capital crunch"), an important empirical issue is distinguishing whether reduced lending results from a reduction in the supply of bank financing or from reduced demand by borrowers for funding. This is not a direct concern in our paper. Our focus is on the extent to which DELR in general makes banks more vulnerable to severe downside risk and risk codependence among banks. This vulnerability can derive from reduced supply of or demand for bank financing, as well as from increased risk-shifting, lower probability of survival, etc.

${ }^{8}$ Results are robust to estimating VaR at the $5 \%$ quantile of the distribution.
} 
banking setting to isolate an accounting policy choice where banks specifically delay recognition of losses that can accumulate and threaten capital during future crises. Third, we find that increases in downside tail risk associated with $D E L R$ are concentrated in periods of economic distress, finding little difference in downside risk between high and low DELR banks during good times.

It is also useful to contrast our analysis with Beatty and Liao [2011], who find that $D E L R$ increases the sensitivity of realized loan growth to bank capital during recessions, suggesting that DELR contributes to a "capital crunch" where capital concerns cause banks to contract lending. This result suggests that accounting policy can have a nontrivial impact on the pro-cyclicality of the supply of bank lending. However, while reduced bank lending can negatively impact bank-dependent borrowers' access to financing, it is not clear what a contraction in lending implies about a bank's vulnerability to negative tail risk. Thus, we extend the literature by showing that DELR significantly increases individual banks' vulnerability to severe drops in equity values. Further, while Beatty and Liao [2011] focus on how $D E L R$ conditions the sensitivity of current lending decisions to bank capital, we find that a bank's capital level conditions the association between DELR and downside risk, where this association is significantly higher for banks with lower regulatory capital levels. Moreover, while increased tail risk vulnerability can result from lower lending volumes as well as other potential negative consequences of DELR, our result is robust to controlling for a bank's current loan growth. This suggests that the influence of DELR on downside risk reflects more than just current reductions in loan growth.

In our final analysis, we extend beyond individual banks to consider how $D E L R$ affects downside risk codependence between individual banks and the entire banking system. First, to examine how downside risk vulnerability of individual banks is influenced by distress of the banking system, we estimate the VaR of individual banks conditional on the state of the aggregate banking sector. We find that, during recessions, downside risk of high DELR banks is relatively more sensitive to the distress of the banking system. That is, when the banking sector as a whole is suffering from a negative economic shock, the equity values of high DELR banks become more vulnerable to severe downside risks. To examine the contribution of individual banks to systemic risk, we reverse the ordering of conditioning and estimate the VaR of the aggregate banking system conditional on the $V a R$ of an individual bank to derive the marginal contribution of an individual bank to systemwide risk. We find that banks with higher DELR contribute more to the risk of severe drops in equity values for the aggregate banking sector. Why does DELR magnify systemic risks? We theorize that downside risk vulnerability at the individual bank level can translate into systemic risk by virtue of DELR creating a common source of risk vulnerability across many high $D E L R$ banks simultaneously. This common DELR source of risk vulnerability can then lead to risk codependence among banks and generate systemic effects from banks acting as part of a herd. 
The rest of the paper is organized as follows. In section 2 we develop the conceptual framework underlying our empirical analysis and discuss related literature. Section 3 contains the empirical analysis of the relation between DELR and stock market liquidity risk. Section 4 discusses our empirical analysis of how DELR influences the tail risk of individual banks, the sensitivity of a bank's tail risk to systemic financial events, and the contribution of individual banks to systemic risk. Section 5 concludes.

\section{Conceptual Framework and Prior Literature}

Section 2.1 discusses DELR and how we empirically estimate it for individual banks. Section 2.2 discusses prior literature on bank transparency and develops our hypothesis that DELR reflects opportunistic accounting policy choices by banks. Section 2.3 lays out our empirical approach to investigating whether $D E L R$ reflects bank transparency by examining relations between $D E L R$ and stock market liquidity risk. Finally, section 2.4 develops the conceptual framework underpinning our empirical analysis of whether DELR increases the tail risk of individual banks and amplifies systemic risk.

\subsection{DELAYED RECOGNITION OF EXPECTED LOAN LOSSES (DELR)}

Loan loss provisioning is a key accounting policy choice that directly influences the volatility and cyclicality of bank earnings, as well as information properties of banks' financial reports with respect to reflecting loan portfolios' risk attributes. While both the Financial Accounting Standards Board (FASB) and International Accounting Standards Board (IASB) have long required use of incurred loss model for loan loss provisioning, the complexity of loan portfolios allows substantial scope for discretion within the prescribed rules (Financial Stability Forum [2009], Dugan [2009]). ${ }^{9}$

Conceptually, loan loss provisions and related loan loss reserves can be viewed as providing a cushion against expected losses while bank capital is a buffer against unexpected losses (e.g., Laeven and Majnoni [2003]). When banks opportunistically delay recognition of expected losses, a current expense is not recorded for some portion of the expected losses. This has several implications. First, DELR can mask a loan portfolio's risk attributes and obscure the true capital cushion by mingling unrecognized expected losses together with capital available to buffer unexpected losses. Second,

\footnotetext{
${ }^{9}$ The incurred loss model specifies that loan losses are recognized only when a loss is probably based on past events and conditions existing at the financial statement date. Both the FASB and IASB have developed new rules for financial instruments that will substantially change the accounting for loan loss provisions. In general, the new rules drop the incurred loss model and adopt a more forward-looking "expected loss" model that will require banks to recognize not only credit losses that have already occurred but also losses that are expected in the future. The FASB and IASB take different approaches to implementing an expected loss framework. It is an open question as to whether the new rules will increase or decrease the role of accounting discretion in loan loss accounting.
} 
because unrecognized expected losses will be recognized on average in the future, DELR creates expected loss overhangs that loom over future bank profits and capital adequacy.

We generate bank-quarter estimates of DELR following Bushman and Williams [2012], Beatty and Liao [2011], and Nichols, Wahlen, and Wieland [2009]. ${ }^{10}$ For each bank-quarter, we estimate the following two equations using a 12-quarter rolling window, requiring the bank to have data for all 12 quarters:

$$
\begin{aligned}
L L P_{t}= & \beta_{0}+\beta_{1} \Delta N P L_{t-1}+\beta_{2} \Delta N P L_{t-2}+\beta_{3} \text { Capital }_{t-1} \\
& +\beta_{4} E B L L P_{t}+\beta_{5} \text { Size }_{t-1}+\varepsilon_{t}, \\
L L P_{t}= & \beta_{0}+\beta_{1} \Delta N P L_{t-1}+\beta_{2} \Delta N P L_{t+2} \beta_{3} \Delta N P L_{t-1}+\beta_{4} \Delta N P L_{t-2} \\
& +\beta_{5} \text { Capital }_{t-1}+\beta_{6} \text { EBLLP }_{t}+\beta_{7} \text { Size }_{t-1}+\varepsilon_{t} .
\end{aligned}
$$

$L L P$ is loan loss provisions scaled by lagged total loans, $\triangle N P L$ is the change in nonperforming loans scaled by lagged total loans, Capital is the tier 1 capital ratio, Ebllp is earnings before loan loss provision scaled by lagged total loans, Size is the natural log of total assets (all variables and their construction are detailed in the appendix). We include Capital to control for banks incentives to manage capital through loan loss provisions (Beatty, Chamberlain, and Magliolo [1995]. Ebllp is included to control for banks' incentives to smooth earnings (Ahmed, Takeda, and Thomas [1999], Bushman and Williams [2012]).

We compute DELR as the incremental $R^{2}$ calculated by subtracting the adjusted $R^{2}$ of equation (1) from that of equation (2). We posit that higher incremental $R^{2}$ is consistent with more timely recognition of expected losses. The idea is that more timely banks recognize loss provisions concurrently with increases in NPL and in anticipation of future nonperformance, while less timely banks delay loss recognition related to contemporaneous NPL innovations and do not anticipate future nonperformance. Each quarter, we rank banks based on their incremental $R^{2}$ and set the indicator variable DELR equal to 1 if the bank is below the median incremental $R^{2}$, and 0 otherwise. That is, $D E L R=1$ for banks that most aggressively delay loss recognition. Descriptive statistics for DELR are included in table 1 , which is discussed further in section 3.1.

\subsection{DISCRETIONARY LOAN LOSS PROVISIONING BEHAVIOR AND BANK TRANSPARENCY}

It is often asserted that banks are inherently more opaque than nonfinancial firms (Morgan [2002], Flannery, Kwan, and Nimalendran [2004,

\footnotetext{
${ }^{10}$ See Beatty and Liao [2014] for an extensive discussion about empirically modeling loan loss provisions.
} 
TA B L E 1

Descriptive Statistics

\begin{tabular}{|c|c|c|c|c|c|c|c|}
\hline \multicolumn{8}{|c|}{$\begin{array}{l}\text { Panel A: Pooled } D E L R \text { regression and descriptive statistics } \\
\text { Dependent Variable: } L L P_{t}\end{array}$} \\
\hline Model & $\Delta N P L_{t+1}$ & $\triangle N P L_{t}$ & $\triangle N P L_{t-1}$ & $\Delta N P L_{t-1}$ & Capital $_{t-2}$ & $E B L L P_{t}$ & Size $_{t-1}$ \\
\hline (1) & & & $\begin{array}{c}0.0754^{* *} \\
(0.030)\end{array}$ & $\begin{array}{c}0.0686^{* * *} \\
(0.028)\end{array}$ & $\begin{array}{c}0.0010 \\
(0.002)\end{array}$ & $\begin{array}{c}-0.0681^{* * * *} \\
(0.025)\end{array}$ & $\begin{array}{l}0.0003^{* * *} \\
(0.000)\end{array}$ \\
\hline$N$ & 11,008 & & & & & & \\
\hline$R^{2}$ & 0.1268 & & & & & & \\
\hline (2) & $\begin{array}{l}0.0660^{* * *} \\
(0.012)\end{array}$ & $\begin{array}{l}0.1679^{* * *} \\
(0.022)\end{array}$ & $\begin{array}{l}0.0702^{* * *} \\
(0.016)\end{array}$ & $\begin{array}{l}0.0492^{* * *} \\
(0.016)\end{array}$ & $\begin{array}{c}-0.0001 \\
(0.002)\end{array}$ & $\begin{array}{c}-0.0254 \\
(0.016)\end{array}$ & $\begin{array}{l}0.0002^{* * *} \\
(0.000)\end{array}$ \\
\hline$N$ & 11,008 & & & & & & \\
\hline$R^{2}$ & 0.2303 & & & & & & \\
\hline
\end{tabular}

Panel B: Descriptive statistics by $D E L R$ partitions

\begin{tabular}{lrrrrrrr} 
& \multicolumn{3}{c}{ HighDELR } & & \multicolumn{3}{c}{ LowDELR } \\
\cline { 2 - 3 } Variables & Mean & Median & StdDev & & Mean & Median & StdDev \\
\hline VaR & -1.509 & -1.319 & 0.717 & & $-1.480^{* *}$ & $-1.309^{*}$ & 0.682 \\
Skew & -0.144 & -0.140 & 0.168 & & $-0.155^{* * *}$ & $-0.150^{* * *}$ & 0.163 \\
$\Delta$ Co VaR $^{i \mid s}$ & -0.588 & -0.488 & 0.580 & & $-0.564^{* *}$ & $-0.472^{* *}$ & 0.554 \\
$\Delta$ Co VaR $^{\text {si }}$ & -0.224 & -0.192 & 0.193 & & $-0.207^{* * *}$ & $-0.178^{* * *}$ & 0.182 \\
Trading & 0.003 & 0.001 & 0.012 & & $0.002^{* *}$ & $0.000^{* *}$ & 0.012 \\
Commercial & 0.147 & 0.131 & 0.135 & & 0.146 & 0.128 & 0.130 \\
Consumer & 0.016 & 0.000 & 0.048 & & 0.015 & 0.000 & 0.045 \\
Real Estate & 0.548 & 0.664 & 0.329 & & $0.559^{*}$ & 0.669 & 0.323 \\
Mismatch & 0.850 & 0.867 & 0.088 & & $0.854^{* *}$ & $0.872^{* *}$ & 0.084 \\
Deposit & 1.190 & 1.136 & 0.288 & & $1.206^{* * *}$ & $1.150^{* * *}$ & 0.287 \\
Revenue Mix & 0.837 & 0.852 & 0.098 & & $0.839^{*}$ & $0.856^{* *}$ & 0.097 \\
Capital & 0.107 & 0.104 & 0.025 & & $0.108^{* *}$ & 0.105 & 0.027 \\
$\beta_{\text {MRKT }}$ & 0.662 & 0.573 & 0.618 & & 0.652 & 0.558 & 0.611 \\
$\sigma_{e}$ & 0.020 & 0.016 & 0.015 & & 0.020 & $0.015^{*}$ & 0.014 \\
Size & 7.817 & 7.553 & 1.560 & & $7.720^{* * *}$ & $7.500^{*}$ & 1.512 \\
MTB & 1.795 & 1.734 & 0.754 & & 1.798 & 1.732 & 0.733 \\
Illiquid & 1.063 & 0.044 & 3.427 & & $1.007^{*}$ & 0.048 & 3.156 \\
Return & 0.002 & -0.008 & 0.166 & 0.002 & -0.011 & 0.164 \\
LoanGrowth & 0.025 & 0.019 & 0.045 & 0.024 & 0.019 & 0.047 \\
\hline
\end{tabular}

Panel A above contains the pooled regression for the sample period 1996-2009. The dependent variable is loan loss provisions scaled by beginning period loans. $\triangle N P L$ is the quarter change in nonperforming loans scaled by beginning total loans. Capital is the tier 1 capital ratio. EBLLP is earnings before provisions and taxes scaled by beginning period total loans. Size is the natural log of beginning period total assets. Standards errors are reported in the parentheses and are clustered by bank and quarter. DELR measures the incremental explanatory power of current and future changes in nonperforming loans on current loan loss provisions.

Panel B above contains the descriptive statistics for the sample period 1996-2009. DELR is the incremental explanatory power of current and future changes in nonperforming loans on current loan loss provisions. LowDELR contains banks with DELR above the median DELR, and HighDELR reflects banks below median. $V a R$ is defined as the one percentile value-at-risk over the quarter, where the value-at is risk is computed over the market value of equity. The variable Skew is defined as $\left(\left(V_{a} R_{50 \%}-V_{a} R_{1 \%}\right)-\left(V_{a} R_{99}-V_{a} R_{50 \%}\right)\right) /\left(V_{a} R_{99 \%}-V_{a} R_{1 \%}\right)$, where the $q \%$ in the $V_{a} R_{q} \%$ represents the percentile over which the value-at-risk is computed for the market value of equity. $\triangle \mathrm{CoVaR} \mathrm{R}^{i \mid s}$ $\left(\triangle C_{o V a R} s^{s i}\right)$ is defined as the sum of the firm's weekly $\Delta \operatorname{CoVaR} R^{i \mid s}\left(\Delta \mathrm{CoVaR} R^{s i}\right)$ over the quarter. Trading is the ratio of trading account assets to total assets. Commercial is total commercial loans scaled by total loans outstanding. Consumer is total consumer loans outstanding scaled by total loans outstanding. Real Estate is total real estate loans outstanding scaled by total loans. Mismatch is the maturity mismatch. Deposits is the banks total deposits scaled by beginning period loans. Revenue Mix is defined as the ratio of noninterest revenue to total revenue. Capital is the firms tier 1 capital ratio. $\beta_{\text {Mrkt }}$ is the firms market beta from a traditional CAPM. $\sigma_{e}$ is the idiosyncratic volatility in equity returns. Size is the natural logarithm of total assets. $M T B$ is the market-to-book ratio of the firm. Illiquid is Amihud [2002] measure of illiquidity. Return is the firm's market adjusted return over the quarter. Loan Growth is the percentage change in total loans over the quarter.

${ }^{* * *},{ }^{* *},{ }^{*}$ indicate the difference across columns is significant at the $0.01,0.05$, and 0.10 level, respectively. 
2013]). This inherent lack of transparency is presumed to derive from the fact that assets on banks' balance sheets reflect investment decisions based on private information about borrowers and projects that is not available to those outside the bank (e.g., Diamond [1984], Boyd and Prescott [1986]). Trading activities may also make banks relatively more opaque as complex trading and derivatives portfolios embed risks that are hard to assess and verify, and trading positions and related risk profiles can be quickly altered in real time (Morgan [2002], Laeven [2013]). A large theory literature explores bank transparency. Overall, this literature shows that, while credible public information about individual banks can enhance the ability of regulators and market participants to monitor and exert discipline on banks' behavior, there are potentially significant endogenous costs associated with transparency.

Consider positive effects of transparency. Financial accounting information plays a fundamental corporate governance role, supporting monitoring by boards of directors, outside investors, and regulators and the exercise of investor rights granted by existing laws (e.g., Bushman and Smith [2001]). Related to this idea, the banking literature posits that transparency can promote bank stability by enhancing market discipline of banks' risk-taking decisions (e.g., Rochet [1992], Blum [2002], Flannery [2001], Cordella and Yeyati [1998]). Market discipline is a process in which market participants use available information to monitor and discipline excessive risk-taking by banks. Market discipline can operate by market participants directly exerting influence on a bank's risk-taking behavior. For example, transparency may enhance ex ante discipline as bank managers anticipate that informed investors will quickly discern increased risk-taking and demand higher yields on their investments. Market discipline can also operate via regulatory intervention triggered by market signals, such as price movements of bank securities (e.g., Stephanou [2010], Flannery [2001]). Further, transparency can limit regulatory forbearance by providing a basis for market participants to exert pressure on bank supervisors to promptly intervene in troubled banks (Rochet [2005], Gallemore [2013]).

Beyond market discipline, transparency can mitigate indiscriminate panic and rollover risk by reducing depositors' and other short-term lenders' uncertainty about the solvency of individual banks (Ratnovski [2013], Gorton and Huang [2006]). ${ }^{11}$ In this vein, Granja [2014] shows that state-level regulations that required banks to report financial statements in local newspapers during the national banking era are associated with a reduction in observed bank failures within the state. As discussed earlier, transparency can reduce financing frictions imposed on banks seeking to raise capital in response to negative balance sheet shocks. The

\footnotetext{
${ }^{11}$ For example, it has been posited that recent bank liquidity crises were caused by increased uncertainty over banks' solvency as assessed by participants in wholesale funding markets (Shin [2009], Goldsmith-Pinkham and Yorulmazer [2010], Huang and Ratnovski [2011]).
} 
existence of financing frictions driven by asymmetric information between bank managers and market participants underpin theories of monetary policy transmission through a bank lending channel (Kashyap and Stein $[1995,2000])$ and capital crunch theories positing that regulatory capital concerns cause banks to restrict lending during economic downturns (Bernanke and Lown [1991], Bolton and Freixas [2006], Van den Heuvel [2009]). ${ }^{12}$

On the negative side, theory posits that transparency can lead to inefficient bank runs driven by coordination failures (Morris and Shin [2002], Chen and Hasan [2006]), cause reputational contagion where the failure of one bank causes creditors in other banks to lose confidence in the bank regulator's competence (Morrison and White [2013]), adversely affect incentives of bank managers and lead them to make inefficient investment decisions (Goldstein and Sapra [2013]), restrict interbank risksharing arrangements (Goldstein and Leitner [2013]), and undermine banks' ability to produce private money (Gorton [2013], Dang, et al. $[2014]) .^{13}$

These conflicting views create a demand for empirical research that can reveal insights into the nature of transparency and when, where, and how it positively or negatively affects banks and the banking system. A key source of bank transparency is publicly disclosed financial reports. In this paper, we explore the possibility that a bank's accounting policy choices are an important determinant of its transparency. While the accounting rules themselves are an important determinant of bank transparency, the application of accounting rules to specific economic situations often allows substantial scope for judgment to be exercised by privately informed bank managers. Accounting discretion may create informational benefits by facilitating the incorporation of private information into accounting reports, but also increases potential for opportunistic accounting behavior by managers that can degrade bank transparency and lead to negative consequences along other dimensions (Beatty and Liao [2014]).

In this paper, we focus on banks' accounting discretion over loan loss provisions as captured by delayed expected loan loss recognition (DELR). The loan book is typically the largest single asset on a bank's balance sheet where the lending activities underlying this portfolio are based on private information not available to those outside of the bank. Loan loss provisions

\footnotetext{
${ }^{12}$ Granja [2013] suggests another benefit of bank transparency, showing that disclosure requirements mitigate information asymmetries in the auctions for failed banks. Specifically, Granja [2013] finds that, when failed banks are subject to more comprehensive disclosure requirements, regulators incur lower costs of closing a bank and retain a lower portion of the failed bank's assets, while bidders that are geographically more distant are more likely to participate in the bidding for the failed bank.

${ }^{13}$ One of the main functions of financial institutions is to create liquidity. An important form of liquidity creation is where banks issue liabilities that can be used to facilitate payments and settlement (e.g., demand deposits, sale and repurchase agreements, or other forms of short-term debt). This is private money.
} 
are accruals of fundamental importance to bank performance, which, as estimates of loan losses based on private information, afford management significant flexibility in making accounting choices that can serve to degrade the ability of outsiders to assess a loan portfolio's true attributes. We hypothesize that DELR is a manifestation of opportunistic loan provisioning behavior that results in reduced bank transparency. ${ }^{14}$ Of course, transparency is a complex, multidimensional construct and the extent to which DELR reflects an important aspect of bank transparency is ultimately an empirical question. As discussed next, we provide evidence consistent with this hypothesis by appealing to a literature that connects a firm's transparency and investors' uncertainty over its fundamentals to properties of the firm's stock market illiquidity.

\subsection{DELR, TRANSPARENCY, AND STOCK MARKET LIQUIDITY RISK}

In general, investors prefer liquid securities as illiquidity is costly (e.g., Amihud, Mendelson, and Pedersen [2005]). A stock's illiquidity level is in essence a transaction cost imposed on trading. Because investors care about a stock's illiquidity at the time they transact, the variability of illiquidity is also important as variability increases uncertainty attached to a position. Liquidity risk refers to the risk that a stock will become illiquid at inopportune times for investors. Liquidity risk reflects an aspect of systematic risk that is reflected in expected stock returns to compensate investors for bearing undiversifiable risk. From the standpoint of firms who wish to raise new equity capital, higher illiquidity levels and liquidity risks represent financing frictions as they manifest in higher expected stock returns demanded by potential investors (Acharya and Petersen [2005]). As discussed in the introduction, an extensive literature links transparency to stock market illiquidity and liquidity risk (e.g., Vayanos [2004], Amihud, Mendelson, and Pedersen [2005], Brunnermeier and Pedersen [2009], Lang and Maffet [2011]).

We follow Amihud [2002] and define illiquidity of a stock as the absolute value of daily stock returns divided by daily trading volume in dollars. Our measure, Illiquidity, is the natural logarithm of average daily illiquidity over the quarter. We also consider two aspects of liquidity risk. The first aspect is co-movement between illiquidity of an individual bank's stock and illiquidity of the aggregate banking sector, which imposes risk on investors as it implies that a bank's stock becomes illiquid when the overall sector becomes illiquid. To estimate this aspect of liquidity risk, we regress daily percentage changes in illiquidity of a bank on daily percentage changes in illiquidity for a value-weighted portfolio of the rest of the banking sector over the quarter (excluding the individual bank). We require an individual

\footnotetext{
${ }^{14}$ Bushman, Hendricks, and Williams [2014] and Dou, Ryan and Zou [2014] provide evidence that $D E L R$ responds to time-varying performance pressures on bank managers, finding that $D E L R$ increases in response to increases in bank competition.
} 
bank to have a minimum of 50 valid trading days during the quarter. Liquidity risk associated with co-movement of bank level liquidity and aggregate illiquidity, $\beta_{B L, A L}$, is the bank-quarter coefficient on changes in aggregate illiquidity.

The second aspect of liquidity risk is the co-movement between individual stock illiquidity and aggregate banking sector stock returns, which captures the extent to which a stock becomes illiquid when the market is down and investors especially value the ability to sell easily. We regress daily percentage changes in illiquidity of the bank on daily stock returns for a valueweighted portfolio of the rest of the banking sector over the quarter (excluding the individual bank). ${ }^{15}$ Liquidity risk associated with co-movement of bank level illiquidity and bank market return, $\beta_{B L, M R}$, is the bank-quarter coefficient on banking sector returns.

Consistent with higher DELR reflecting lower bank transparency, we predict that Illiquidity, $\beta_{B L, A L}$ and $\beta_{B L, M R}$ will be higher for high DELR firms, especially during recessions.

\subsection{DELR, DOWNSIDE RISK OF INDIVIDUAL BANKS, AND SYSTEMIC RISK}

Two fundamental approaches to bank regulation can be distinguished: a micro-prudential and a macro-prudential approach. A micro-prudential approach is aimed at preventing the costly failure of individual banks, where a macro-prudential approach seeks to safeguard the financial system as a whole (Hanson, Kashyap, and Stein [2011]). Our analyses contain elements of both perspectives. We examine the relation between DELR and vulnerability of individual banks to downside risk, as well as the extent to which DELR conditions the level of risk codependence among banks. As discussed previously, DELR, operating both through expected loss overhangs and reduced transparency, can create capital inadequacy concerns that increase the vulnerability to severe downside risk of individual banks and of the banking system as a whole. The challenge is to devise a research design powerful enough to explore connections between DELR and bank and banking system vulnerability to severe downside risk.

To investigate downside risk, we follow the approach developed by Adrian and Brunnermeier [2011] and estimate conditional, time-varying distributions over future equity returns. We then investigate how DELR impacts the lower tail of this distribution. We capture tail risk using a valueat-risk $(\mathrm{VaR})$ construct. VaR measures the potential loss in value of a risky asset or portfolio over a defined period for a given confidence interval. Thus, if the VaR of a bank's equity returns is $-15 \%$ at a one-week, $99 \%$ confidence level, there is a only a $1 \%$ chance that the bank's equity value will drop more than $15 \%$ over any given week. Formally, let $X$ represent the

\footnotetext{
${ }^{15}$ In our empirical analyses we estimate liquidity risk by reference to the illiquidity and returns of the aggregate banking sector. All results are robust to using the overall stock market as our reference portfolio.
} 
percentage change in the market value of equity for a bank. Then $V a R$ at a $1 \%$ probability threshold is defined implicitly as

$$
\text { probability }(X \leq V a R)=1 \% \text {. }
$$

We use quantile regression to estimate time-varying VaRs. With quantile regression, the predicted value for a given quantile can be interpreted as the expected outcome at the given quantile, making it straightforward to estimate time-varying $\mathrm{VaR}$ at any quantile. Given our focus on severe downside events, $\mathrm{VaR}$ at a $1 \%$ probability threshold is a negative number indicating with $1 \%$ probability that the realization of random variable $X$ will be $V a R$ or more extreme over a given time horizon. The more negative is $V a R$, the larger is the potential drop in the market value of a bank's equity at a fixed $1 \%$ probability. Holding the probability of loss constant across banks, estimated VaRs allow us to assess relative downside risk across banks. We hypothesize that, relative to low DELR banks, high DELR banks will exhibit significantly higher increases in risk of severe drops in the market value of a bank's equity during recessions (i.e., more negative $V a R$ ).

We also examine the association between DELR and systemic risk. Following the recent financial crisis, there has been considerable interest in modeling and measuring systemic risk. There is no agreed upon approach to this measurement (e.g., Bisias et al. [2012] Hansen [2014]). One important stream of literature exploits the high-frequency observability of bank's equity prices to extract measures of systemic risk. Some papers in this stream use contingent claims analysis (e.g., Gray, Merton, and Bodie [2008], Gray and Jobst [2009]), while others focus on codependence in the tails of equity returns using reduced form approaches (Acharya et al. [2010], Adrian and Brunnermeier [2011]). ${ }^{16}$ Given that equity prices impound the market's expectations about banks' future prospects, equity-based measures of bank tail risk reflect risk assessments deriving from a wide range of underlying sources of vulnerability. The focus on equity value is also valuable because it reflects the market's expectations about a bank's (the banking system's) capital level. For example, Acharya et al. [2010] use equity values to estimate a financial institution's contribution to systemic risk by measuring its propensity to be undercapitalized when the system as a whole is undercapitalized, empirically showing that their measure possesses substantial power for predicting emerging risks during the financial crisis of 2007 2009.

We adopt the conditional VaR approach (i.e., CoVaR) developed by Adrian and Brunnermeier [2011]. In this approach, codependence is captured by using quantile regression to estimate the VaR of the entire banking system conditional on the VaR of an individual bank, and by reversing

\footnotetext{
${ }^{16}$ Correlation is a measure of linear codependence, where the term codependence encompasses a wider range of relations that can exist between random variables. For example, the tail dependence of a pair of random variables describes their co-movements in the tails of the distributions.
} 
the order of conditioning to also estimate $V a R$ of the individual bank conditional on the VaR of the banking system. Adrian and Brunnermeier [2011] demonstrate that these two measures of codependence are not symmetric, implying that each measure captures a distinct aspect of a bank's risk profile.

To implement our first analysis of the relation between DELR and banking system-wide outcomes, we estimate the VaR of each individual bank conditional on the state of the banking system. Specifically, we define $\mathrm{CoVaR}^{i \mid s y s t e m}$ as $\operatorname{VaR}^{i}$ of bank $i$ at a $1 \%$ probability threshold conditional on the $V a R^{\text {system }}$ of the entire banking system. The difference between $\mathrm{CoVaR}^{i \mid s y s t e m}$ conditional on the banking system being in distress (e.g., system outcome $\left.=V a R_{q=1 \%}^{\text {system }}\right)$ and $\mathrm{CoVaR} R^{i \mid \text { system }}$ conditional on the median state of the banking system $\left(V_{a} R_{q=50 \%}^{\text {system }}\right), \Delta C o V a R^{i \mid s y s t e m}$, captures the marginal contribution of the banking system to downside risk of bank $i$. We predict that $\Delta C o V a R^{i \mid s y s t e m}$ will decrease more (become more negative) during recessions for banks with higher levels of $D E L R$.

Finally, to examine how DELR impacts the contribution of individual banks to systemic risk, we estimate the VaR ${ }^{\text {system }}$ of the banking system conditional on the state of individual bank $i$. We define CoVaR ${ }^{\text {system } \mid i}$ as $V a R_{1 \%}^{\text {system }}$ of the banking system conditional on the state of bank $i$. In this case, the difference between $\mathrm{CoVaR}^{\text {system|i }}$ conditional on bank $i$ being in distress (e.g., bank $i$ outcome $=V a R_{q=1 \%}^{i}$ ) and $C o V a R^{\text {system|i }}$ conditional on the median state of bank $i$ (bank $i$ outcome $=V a R_{q=50 \%}^{i}$ ), $\Delta$ CoVaR $R^{\text {system } \mid}$, captures the marginal contribution of bank $i$ to the risk that the banking system will experience a severe drop in the aggregate market value of equity or total assets. We predict that $\Delta C o V a R^{s y s t e m \mid i}$ will decrease more (become more negative) during recessions for banks with higher levels of DELR.

As stressed by Adrian and Brunnermeier [2011], $\Delta$ CoVaR $R^{\text {system|i }}$ captures both causal contributions of an individual bank to systemic risk (e.g., distress at large, interconnected banks directly causing negative spillover effects on others) and contributions driven by herd reactions to a common factor. In isolation, DELR is an idiosyncratic decision of an individual bank responding to some sort of performance pressure. It is not obvious whether, and if so how, the accounting decisions of an individual bank could amplify the bank's influence on the risk of a severe downside hit to the entire banking system. We theorize that, when a group of banks who, for idiosyncratic reasons, all significantly delay loss recognition in good times, all group members will simultaneously face the consequences of loss overhangs and financing frictions correlated during a downturn. As a result, the codependence of tail risks among such banks will be significant, creating a systemic effect from banks acting as part of a herd (Brunnermeier et al. [2009]). That is, DELR acts like a systematic risk factor that inflicts a negative shock on the entire group of DELR banks, thereby inflicting measurable pain on the entire banking system. 


\section{DELR and Equity Financing Frictions: Data, Methodology, and Results}

\subsection{DATA AND DESCRIPTIVE STATISTICS}

Our quarterly data come primarily from Compustat, Bank Call reports, and CRSP. Our sample starts in 1993 and goes until the end of 2009. ${ }^{17}$ To ensure that mergers and acquisitions do not impact our results, we eliminate observations that had any M\&A activity over a given quarter. We measure economic cycles using NBER dates to define recessionary periods ("Bust") and nonrecessionary ("Boom") periods. There are two recessionary periods in our sample, March 2001 to November 2002, and December 2007 to June 2009.

Earlier, we developed our bank-quarter measure of DELR as the incremental $R^{2}$ in explaining variation in current loan loss provisions from adding current and future changes in nonperforming loans over and above lagged changes in nonperforming loans. In table 1, panel A, we illustrate the DELR estimation by reporting equations (1) and (2) estimated for the pooled sample of all bank-quarter observations. We see that the difference in $R^{2}$ between (2) and (1) for this pooled sample equals $0.103(0.230-$ $0.127)$. Also noteworthy in the pooled regression is that the coefficients on all $\triangle N P L$ variables are positive and significant, and that the coefficient on $\triangle N P L_{t}$ is much larger than the coefficient on $\triangle N P L_{t+1}$. When we estimate $D E L R$ for individual bank quarters, we see that DELR has mean (median) value of $0.167(0.114)$ and exhibits significant cross-sectional variation with a standard deviation of $0.162,0.045$ at the $25^{\text {th }}$ percentile and 0.237 at the $75^{\text {th }}$ percentile.

Table 1, panel B, splits the sample into high and low DELR partitions and examines how the key bank level control variables used in our regression analyses differ across groups. This variable set consists of the following (all variables are described in detail in the appendix). Trading, defined as the ratio of the trading portfolio to total assets, controls for differences in the composition of banks' securities portfolios. Securities classified as trading are accounted for using fair value accounting, with gains or losses from value changes included in net income. We control for the composition of the loan portfolio with Commercial, Consumer, and Real Estate, which represent commercial, consumer, and real estate loans, respectively, all scaled by total loans. Mismatch, defined as short-term liabilities net of cash divided by total liabilities, controls for differences in funding risk associated with short-term debt. To complete our balance sheet controls, we include $D e^{-}$ posits, defined as total deposits scaled by lagged total loans, and Capital, the tier 1 capital ratio.

\footnotetext{
${ }^{17}$ Bank Compustat does not report quarterly nonperforming levels prior to 1993 . Due to the data demands for estimating DELR using 12-quarter rolling windows, our analysis spans the period 1996-2009.
} 
To control for differences in revenue mix, we include Revenue Mix, the ratio of noninterest revenue to total revenue. ${ }^{18}$ We include two equity risk measures, $\sigma_{e}$, the standard deviation of daily equity returns over the quarter, and $\beta_{M r k t}$, the bank's market beta from a traditional CAPM model estimated on daily returns over the prior quarter. We include the bank's stock return, Return, to control for the information set that bank managers' have for determining loan loss provisions. In terms of the manager's information set, we note that equity return volatility also proxies for information flows to the market. We also include LoanGrowth, defined as the percentage change in loans on the balance sheet over the quarter, as loan growth has been posited to be an important driver of the riskiness of banks (Foos, Norden, and Weber [2010]). Finally, we control for Size with the $\log$ of total assets, and marketto-book $(M T B)$ as a control for expected growth differences. Table 1, panel $\mathrm{B}$, reveals that many of the control variables differ significantly across the low and high DELR groups, further justifying their inclusion in the analysis.

\subsection{DELR, LIQUIDITY RISK, AND ILLIQUIDITY}

As described above, we follow Amihud [2002] and define illiquidity of a stock as the absolute value of daily stock returns divided by daily trading volume in dollars. Liquidity risk reflects how closely bank-level stock market illiquidity co-moves with aggregate banking sector illiquidity $\left(\beta_{B L, A L)}\right.$ and market return $\left(\beta_{B L, M R}\right)$. To estimate liquidity risk, we regress daily percent changes in illiquidity of a bank on daily percent changes in illiquidity (market returns) for a value-weighted portfolio of the rest of the banking sector over the quarter (excluding the individual bank). To the extent that $D E L R$ reflects bank transparency, we expect illiquidity and liquidity risk to increase with the extent of $D E L R$, and that this association will be stronger during crisis periods. To examine the effects of DELR on our proxies for a bank's liquidity risk ( $\left.\beta_{B L, A L}, \beta_{B L, M R}\right)$ and illiquidity level (Illiquidity), we estimate the following OLS pooled regressions with year fixed effects, clustering the standard errors by both calendar quarter and bank to correct for possible time-series and cross-sectional correlation:

$$
\begin{aligned}
\beta_{B L, A L, t}\left(\beta_{B L, M R, t,} \text { Illiquidity }_{t}\right)= & \delta_{0}+\delta_{1} D E L R_{t-1} \\
& + \text { Controls }+ \text { YearFE }+\varepsilon_{t} .
\end{aligned}
$$

We estimate equation (3) for three samples: (1) pooled, (2) "boom" subsample, and (3) "bust" subsample (i.e., quarters designated by NBER as recessions). As controls we include the following which were defined earlier

\footnotetext{
${ }^{18}$ Brunnermeier, Dong, and Palia [2012] find that a bank's contribution to system-wide risk is increasing in the extent to which it relies on noninterest revenue (i.e., Revenue Mix). Given that we control for Revenue Mix, the effects of DELR we document in our CoVaR $R^{\text {system|i }}$ are orthogonal to the effects documented in Brunnermeier, Dong, and Palia [2012].
} 
and in the appendix: Trading, Commercial, Consumer, Real Estate, Mismatch, Deposits, Revenue Mix, Capital, $\beta_{M r k t}, \sigma_{e}$, Size, MTB, and LoanGrowth.

Table 2, panel $\mathrm{A}$, reports the results for $\beta_{B L, A L}$. In the pooled analysis, we find a positive relation between $D E L R$ and $\beta_{B L, A L}(0.0364$, significant at the $10 \%$ level). Moving to the boom and bust subsamples, we find a positive and significant relation between $D E L R$ and $\beta_{B L, A L}$ in the "bust" subsample, but not the "boom" sample. The reported coefficient for DELR in bust periods is 0.1288 ( $p$-value $<0.01)$. Importantly, the positive coefficient in the "bust" period is significantly different from the coefficient in the "boom" period at the 0.01 level.

In table 2, panel $\mathrm{B}$, we find similar results for $\beta_{B L, M R}$. Specifically, we find a positive coefficient on DELR (coefficient $=0.0034, p$-value $<0.05$ ) for the bust subsample and insignificant coefficient for the boom subsample. Overall, across the two different proxies for liquidity risk, we find evidence that liquidity co-movement is significantly higher for high $D E L R$ banks relative to low DELR banks, and this effect is concentrated in recessionary periods.

Table 2, panel C, reports the result for illiquidity levels. In the pooled analysis, we find a positive relation between DELR and Illiquidity $(0.2175$, significant at the $10 \%$ level). When we turn to the subsamples, similar to the liquidity risk results, there is a positive and significant relationship between DELR and Illiquidity in the bust subsample, but not the boom sample. The reported coefficient for DELR in busts is 0.6421 (significant at the $5 \%$ level). Further, the positive coefficient in the bust period is significantly different from the coefficient in the boom period at the 0.05 level, consistent with illiquidity being relatively higher for high $D E L R$ banks during recessions.

Consistent with $D E L R$ reducing bank transparency and increasing investor uncertainty about bank fundamentals, we find that DELR is associated with higher illiquidity levels and liquidity risks during recessions. Higher illiquidity levels and liquidity risks imply higher equity financing costs, which can impede access to new equity financing needed to replenish capital depleted by recessionary losses. Further, increased co-movement between bank-level illiquidity and banking sector illiquidity and returns suggests that high DELR banks as a group may simultaneously face elevated financing frictions and enhanced opportunities to engage in risk-shifting behavior in crisis periods.

\section{DELR and Downside Risk}

The previous section provides evidence consistent with DELR reducing bank transparency as manifested in greater financing frictions. In this section, we examine whether $D E L R$ is associated with increased vulnerability of banks to downside tail risks. We posit that the contribution of DELR to increased downside vulnerability is driven by direct consequences of bank transparency and loss overhangs, as well as significant interactions between the two. In terms of interaction effects, there are a number of 
T A B L E 2

DELR, Illiquidity Level, and Liquidity Risk

\begin{tabular}{|c|c|c|c|c|}
\hline \multicolumn{5}{|c|}{$\begin{array}{l}\text { Panel A: Liquidity risk: Co-movement of bank level illiquidity with aggregate illiquidity } \\
\qquad \begin{array}{c}\text { Dependent Variable: } \beta_{B L, A L} \\
\end{array}\end{array}$} \\
\hline Variables & Predictions & Pooled & Boom & Bust \\
\hline$D E L R_{t-1}$ & + & $\begin{array}{c}0.0364^{*} \\
(0.0228)\end{array}$ & $\begin{array}{c}0.0119 \\
(0.0166)\end{array}$ & $\begin{array}{c}0.1288^{* * *} \\
(0.0539)^{\dagger+}\end{array}$ \\
\hline Trading $_{t-1}$ & & $\begin{array}{c}1.1023 \\
(0.8760)\end{array}$ & $\begin{array}{c}1.9066^{* *} \\
(0.7850)\end{array}$ & $\begin{array}{r}-2.9925 \\
(3.5654)\end{array}$ \\
\hline Commercial $_{t-1}$ & & $\begin{array}{c}0.0472 \\
(0.1018)\end{array}$ & $\begin{array}{r}-0.1057^{*} \\
(0.0610)\end{array}$ & $\begin{array}{c}0.4982^{*} \\
(0.2780)\end{array}$ \\
\hline Consumer $_{t-1}$ & & $\begin{array}{c}-0.7804^{* * * *} \\
(0.2234)\end{array}$ & $\begin{array}{c}-0.2711 \\
(0.2362)\end{array}$ & $\begin{array}{c}-1.6661^{* * *} \\
(0.2920)\end{array}$ \\
\hline Real Estate $e_{t-1}$ & & $\begin{array}{c}0.0793 \\
(0.0600)\end{array}$ & $\begin{array}{c}0.0676 \\
(0.0423)\end{array}$ & $\begin{array}{c}0.0934 \\
(0.2052)\end{array}$ \\
\hline Mismatch $_{t-1}$ & & $\begin{array}{c}-0.1223 \\
(0.1198)\end{array}$ & $\begin{array}{c}0.0495 \\
(0.0747)\end{array}$ & $\begin{array}{c}-0.7837^{* *} \\
(0.3811)\end{array}$ \\
\hline Deposits $_{t-1}$ & & $\begin{array}{c}0.0046 \\
(0.0335)\end{array}$ & $\begin{array}{c}-0.0455 \\
(0.0283)\end{array}$ & $\begin{array}{c}0.2380^{* * *} \\
(0.0648)\end{array}$ \\
\hline Revenue Mix $x_{t-1}$ & & $\begin{array}{r}-0.0768^{*} \\
(0.0458)\end{array}$ & $\begin{array}{c}0.0508 \\
(0.1013)\end{array}$ & $\begin{array}{c}-0.7789^{* *} \\
(0.3372)\end{array}$ \\
\hline Capital $_{t-1}$ & & $\begin{array}{c}-0.0021 \\
(0.6380)\end{array}$ & $\begin{array}{c}0.1339 \\
(0.4518)\end{array}$ & $\begin{array}{c}0.1421 \\
(1.3868)\end{array}$ \\
\hline$\beta_{M r k t}$ & & $\begin{array}{c}0.0078 \\
(0.0135)\end{array}$ & $\begin{array}{c}0.0013 \\
(0.0144)\end{array}$ & $\begin{array}{c}0.0114 \\
(0.0290)\end{array}$ \\
\hline$\sigma_{e, t-1}$ & & $\begin{array}{c}0.8825 \\
(1.1986)\end{array}$ & $\begin{array}{c}0.5223 \\
(1.3322)\end{array}$ & $\begin{array}{c}0.5657 \\
(2.2223)\end{array}$ \\
\hline Size $_{t-1}$ & & $\begin{array}{r}0.0249^{*} \\
(0.0144)\end{array}$ & $\begin{array}{c}0.0206 \\
(0.0161)\end{array}$ & $\begin{array}{c}0.0538 \\
(0.0374)\end{array}$ \\
\hline$M T B_{t-1}$ & & $\begin{array}{c}0.0033 \\
(0.0143)\end{array}$ & $\begin{array}{c}0.0097 \\
(0.0164)\end{array}$ & $\begin{array}{c}-0.0572 \\
(0.0628)\end{array}$ \\
\hline LoanGrowth $_{t-1}$ & & $\begin{array}{c}0.0857 \\
(0.2766)\end{array}$ & $\begin{array}{c}0.1202 \\
(0.2192)\end{array}$ & $\begin{array}{r}-0.3161 \\
(0.9763)\end{array}$ \\
\hline Fixed Effect & & Year & Year & Year \\
\hline$N$ & & 7,883 & 6,168 & 1,715 \\
\hline $\operatorname{Adj} R^{2}$ & & 0.0172 & 0.0193 & 0.0306 \\
\hline
\end{tabular}

Panel B: Liquidity risk: Co-movement of bank level illiquidity with market returns

\begin{tabular}{|c|c|c|c|c|}
\hline \multirow[b]{2}{*}{ Variables } & \multirow[b]{2}{*}{ Prediction } & \multicolumn{3}{|c|}{ Dependent Variable: $\beta_{B L, M R}$} \\
\hline & & Pooled & Boom & Bust \\
\hline \multirow[t]{2}{*}{$D E L R_{t-1}$} & + & 0.0013 & 0.0005 & $0.0034^{* *}$ \\
\hline & & $(0.0028)$ & $(0.0040)$ & $(0.0016)^{\dagger \dagger}$ \\
\hline \multirow[t]{2}{*}{ Trading $_{t-1}$} & & -0.0031 & 0.0259 & -0.0746 \\
\hline & & $(0.0591)$ & $(0.0834)$ & $(0.0756)$ \\
\hline \multirow[t]{2}{*}{ Commercial $_{t-1}$} & & -0.0095 & -0.0183 & 0.0155 \\
\hline & & $(0.0107)$ & $(0.0113)$ & $(0.0094)$ \\
\hline \multirow{2}{*}{ Consumer $_{t-1}$} & & $0.0685^{* *}$ & 0.0900 & 0.0527 \\
\hline & & $(0.0345)$ & $(0.0612)$ & $(0.0390)$ \\
\hline \multirow{2}{*}{ Real Estate Et- $_{1}$} & & 0.0048 & -0.0056 & $0.0398^{*}$ \\
\hline & & $(0.0112)$ & $(0.0076)$ & $(0.0206)$ \\
\hline \multirow[t]{2}{*}{ Mismatch $_{t-1}$} & & -0.0004 & 0.0142 & $-0.0575^{*}$ \\
\hline & & $(0.0120)$ & $(0.0123)$ & $(0.0336)$ \\
\hline \multirow[t]{2}{*}{ Deposits $_{t-1}$} & & 0.0196 & 0.0177 & 0.0254 \\
\hline & & $(0.0157)$ & $(0.0195)$ & $(0.0218)$ \\
\hline
\end{tabular}


TAB L E 2-Continued

\begin{tabular}{|c|c|c|c|c|}
\hline \multicolumn{5}{|c|}{$\begin{array}{r}\text { Panel B: Liquidity risk: Co-movement of bank level illiquidity with market returns } \\
\text { Dependent Variable: } \beta_{B L, M R}\end{array}$} \\
\hline Variables & Prediction & Pooled & Boom & Bust \\
\hline Revenue Mix $x_{t-1}$ & & $\begin{array}{r}-0.0084^{*} \\
(0.0043)\end{array}$ & $\begin{array}{r}-0.0136^{*} \\
(0.0074)\end{array}$ & $\begin{array}{c}0.0045 \\
(0.0150)\end{array}$ \\
\hline Capital $_{t-1}$ & & $\begin{array}{r}-0.1557 \\
(0.1102)\end{array}$ & $\begin{array}{r}-0.0719 \\
(0.0975)\end{array}$ & $\begin{array}{r}-0.3788 \\
(0.3071)\end{array}$ \\
\hline$\beta_{M r k t}$ & & $\begin{array}{c}0.0007 \\
(0.0035)\end{array}$ & $\begin{array}{r}-0.0019 \\
(0.0025)\end{array}$ & $\begin{array}{l}0.0094^{* * *} \\
(0.0030)\end{array}$ \\
\hline$\sigma_{e, t-1}$ & & $\begin{array}{r}-0.2100^{* *} \\
(0.1063)\end{array}$ & $\begin{array}{r}-0.0707 \\
(0.2674)\end{array}$ & $\begin{array}{l}-0.4279^{* * *} \\
(0.1192)\end{array}$ \\
\hline Size $_{t-1}$ & & $\begin{array}{r}-0.0005 \\
(0.0005)\end{array}$ & $\begin{array}{r}-0.0003 \\
(0.0006)\end{array}$ & $\begin{array}{r}-0.0017 \\
(0.0012)\end{array}$ \\
\hline$M T B_{t-1}$ & & $\begin{array}{c}-0.0025 \\
(0.0023)\end{array}$ & $\begin{array}{c}-0.0009 \\
(0.0023)\end{array}$ & $\begin{array}{r}-0.0073 \\
(0.0045)\end{array}$ \\
\hline LoanGrowth $_{t-1}$ & & $\begin{array}{c}-0.0102 \\
(0.0315)\end{array}$ & $\begin{array}{c}-0.0064 \\
(0.0309)\end{array}$ & $\begin{array}{c}-0.0162 \\
(0.0354)\end{array}$ \\
\hline Fixed Effects & & Year & Year & Year \\
\hline$N$ & & 7,883 & 6,168 & 1,715 \\
\hline $\operatorname{Adj} R^{2}$ & & 0.0034 & 0.0034 & 0.0126 \\
\hline
\end{tabular}

Panel C: Illiquidity level

\begin{tabular}{|c|c|c|c|c|}
\hline \multirow[b]{2}{*}{ Variables } & \multirow[b]{2}{*}{ Prediction } & \multicolumn{3}{|c|}{ Dependent Variable: Illiquidity } \\
\hline & & Pooled & Boom & Bust \\
\hline \multirow[t]{2}{*}{$\overline{D E L R_{t-1}}$} & + & $0.2175^{*}$ & 0.0376 & $0.6421^{* *}$ \\
\hline & & $(0.1258)$ & $(0.0953)$ & $(0.3313)^{\dagger \dagger}$ \\
\hline \multirow{2}{*}{ Trading $_{t-1}$} & & $-31.3215^{* * * *}$ & $-26.3751^{* * *}$ & $-30.5435^{* *}$ \\
\hline & & $(8.9759)$ & $(9.0888)$ & $(13.7935)$ \\
\hline \multirow{2}{*}{ Commercial $_{t-1}$} & & $1.0492^{*}$ & 0.7732 & $1.7338^{*}$ \\
\hline & & $(0.6049)$ & $(0.5803)$ & $(1.0233)$ \\
\hline \multirow[t]{2}{*}{ Consumer $_{t-1}$} & & $9.4837^{* * *}$ & $6.7611^{*}$ & $7.0400^{*}$ \\
\hline & & $(3.6120)$ & $(3.5574)$ & $(3.9744)$ \\
\hline \multirow[t]{2}{*}{ Real Estate $t_{t-1}$} & & $1.2225^{* * *}$ & $1.1418^{* * *}$ & $1.5164^{* *}$ \\
\hline & & $(0.4071)$ & $(0.4324)$ & $(0.6634)$ \\
\hline \multirow[t]{2}{*}{ Mismatch $_{t-1}$} & & 1.4418 & 1.2000 & 2.9349 \\
\hline & & $(1.1317)$ & $(0.9821)$ & $(2.8214)$ \\
\hline \multirow[t]{2}{*}{ Deposits $_{t-1}$} & & -0.6948 & -0.5685 & $-1.8668^{*}$ \\
\hline & & $(0.5316)$ & $(0.4548)$ & $(1.0225)$ \\
\hline \multirow{2}{*}{ Revenue Mix $x_{t-1}$} & & $2.6508^{* *}$ & 1.1855 & 2.8435 \\
\hline & & $(1.2411)$ & $(0.8407)$ & $(1.9664)$ \\
\hline \multirow[t]{2}{*}{ Capital $_{t-1}$} & & 0.2261 & 0.7423 & 9.2229 \\
\hline & & $(4.2452)$ & $(3.9565)$ & (7.6438) \\
\hline \multirow[t]{2}{*}{$\beta_{M r k t}$} & & $1.5268^{* * *}$ & $1.1705^{* * *}$ & $2.9314^{* * *}$ \\
\hline & & $(0.2542)$ & $(0.2055)$ & $(0.4928)$ \\
\hline \multirow[t]{2}{*}{$\sigma_{e, t-1}$} & & $-71.2991^{* * *}$ & $-72.8816^{* * *}$ & $-64.9737^{\text {*** }}$ \\
\hline & & (12.7354) & (19.0261) & (12.6813) \\
\hline \multirow[t]{2}{*}{ Size $_{t-1}$} & & $0.4873^{* * *}$ & $0.3817^{* * *}$ & $0.5601^{* *}$ \\
\hline & & $(0.0976)$ & $(0.0790)$ & $(0.2199)$ \\
\hline \multirow[t]{2}{*}{$M T B_{t-1}$} & & 0.0266 & 0.0725 & -0.0672 \\
\hline & & $(0.1000)$ & $(0.0807)$ & $(0.1883)$ \\
\hline LoanGrowth $_{t-1}$ & & $3.0178^{* *}$ & $2.9277^{* * * *}$ & $5.9590^{* *}$ \\
\hline
\end{tabular}


T A B L E 2-Continued

\begin{tabular}{lccc}
\hline \hline & $(1.1878)$ & $(1.1303)$ & $(2.9500)$ \\
Fixed Effects & Year & Year & Year \\
$N$ & 9,232 & 6,936 & 1,932 \\
Adj $R^{2}$ & 0.1815 & 0.1759 & 0.2333 \\
\hline
\end{tabular}

Panel A reports OLS pooled regressions over the time period 1996-2009. The dependent variable is $\beta_{B L, A L}$, defined as the coefficient from a regression of changes in firm illiquidity on changes in bank sector illiquidity estimated over the quarter. $D E L R$ (i.e., less timely banks) is an indicator variable set equal to 1 if a bank's DELR is below the median DELR, and zero otherwise. Trading is the ratio of trading account assets to total assets. Commercial is total commercial loans scaled by total loans outstanding. Consumer is total consumer loans outstanding scaled by total loans outstanding. Real Estate is total real estate loans outstanding scaled by total loans. Mismatch is the maturity mismatch. Deposits is the banks total deposits scaled by beginning period loans. Revenue Mix is defined as the ratio of noninterest revenue to total revenue. Capital is the firms tier 1 capital ratio. $\beta_{M r k t}$ is the firms market beta from a traditional CAPM. $\sigma_{e}$ is the idiosyncratic volatility in equity returns. Size is the natural logarithm of total assets. MTB is the market-tobook ratio of the firm. LoanGrowth is the percentage change in total loans over the quarter. Bust years are defined using the NBER dates for recessionary periods. Year-fixed effects are included in all regressions and standard errors are reported in parentheses and are clustered by both bank and calendar quarter.

Panel B reports OLS pooled regressions over the time period 1996-2009. The dependent variable is $\beta_{B L, M R}$, defined as the coefficient from a regression of changes in firm illiquidity on the bank sector return estimated over the quarter. DELR (i.e., less timely banks) is an indicator variable set equal to 1 if a bank's DELR is below the median DELR, and zero otherwise. Trading is the ratio of trading account assets to total assets. Commercial is total commercial loans scaled by total loans outstanding. Consumer is total consumer loans outstanding scaled by total loans outstanding. Real Estate is total real estate loans outstanding scaled by total loans. Mismatch is the maturity mismatch. Deposits is the banks total deposits scaled by beginning period loans. Revenue Mix is defined as the ratio of noninterest revenue to total revenue. Capital is the firms tier 1 capital ratio. $\beta_{M r k t}$ is the firms market beta from a traditional CAPM. $\sigma_{\rho}$ is the idiosyncratic volatility in equity returns. Size is the natural logarithm of total assets. MTB is the market-to-book ratio of the firm. LoanGrowth is the percentage change in total loans over the quarter. Bust years are defined using the NBER dates for recessionary periods. Year-fixed effects are included in all regressions and standard errors are reported in parentheses and are clustered by both bank and calendar quarter.

Panel C reports OLS pooled regressions over the time period 1996-2009. The dependent variable is Illiquidity. Illiquidity is defined as log of illiquidity (Amihud [2002]). DELR (i.e., less timely banks) is an indicator variable set equal to 1 if a bank's DELR is below the median DELR, and zero otherwise. Trading is the ratio of trading account assets to total assets. Commercial is total commercial loans scaled by total loans outstanding. Consumer is total consumer loans outstanding scaled by total loans outstanding. Real Estate is total real estate loans outstanding scaled by total loans. Mismatch is the maturity mismatch. Deposits is the banks total deposits scaled by beginning period loans. Revenue Mix is defined as the ratio of noninterest revenue to total revenue. Capital is the firms tier 1 capital ratio. $\beta_{\text {Mrkt }}$ is the firms market beta from a traditional CAPM. $\sigma_{e}$ is the idiosyncratic volatility in equity returns. Size is the natural logarithm of total assets. MTB is the market-to-book ratio of the firm. LoanGrowth is the percentage change in total loans over the quarter. Bust years are defined using the NBER dates for recessionary periods. Year-fixed effects are included in all regressions and standard errors are reported in parentheses and are clustered by both bank and calendar quarter.

${ }^{* * *},{ }^{* *},{ }^{*}$ indicate significance at the $0.01,0.05$, and 0.10 , respectively.

${ }^{\mathrm{i}}+{ }^{\prime},{ }^{\dagger},{ }^{\dagger}$ indicate that the difference between boom and bust coefficients are significant at the $0.01,0.05$, and 0.10 , respectively.

ways that capital adequacy concerns driven by loss overhangs could interact with transparency to increase banks' susceptibility to downside risk. For example, DELR could threaten capital adequacy via loss overhangs while simultaneously inhibiting new financing by degrading transparency and increasing financing frictions. It is also plausible that DELR could threaten capital adequacy via loss overhangs and thus increase banks' incentives to engage in risk-shifting, while simultaneously weakening market discipline over risk-taking by reducing transparency. While associations between DELR and loss overhang, financing frictions, and risk-shifting have been empirically documented, disentangling precisely how these forces combine 
to influence downside risk is beyond the scope of our paper. ${ }^{19}$ However, in section 4.3 below, we do investigate if the impact of DELR on downside risk is a function of capital inadequacy concerns by examining the extent to which the association between DELR and risk is higher for firms with low capital levels.

In this section we investigate the relation between DELR and future downside risk at the individual bank level (section 4.1), how DELR impacts the sensitivity of individual banks' downside risk to system distress (section 4.2), the extent to which a bank's tier-1 capital level conditions the relation between DELR and downside risk of individual banks (section 4.3), and, finally, how DELR affects the contribution of individual banks to systemic risk (section 4.4).

\subsection{DELR AND INDIVIDUAL BANKS' DOWNSIDE TAIL RISK}

We capture tail risk using estimated value-at-risk ( $V a R)$ at the $1 \%$ quantile. VaR measures the potential loss in value of a risky asset or portfolio over a defined period for a given confidence interval. Following Adrian and Brunnermier [2011], we use quantile regression to estimate time varying VaRs. With quantile regression, the predicted value for a given quantile $(q \%)$ can be interpreted as the expected outcome at the given quantile, making it straightforward to estimate time-varying $\mathrm{VaR}$ at any quantile.

We measure downside risk with respect to the distribution over changes in the market values of a bank's equity (i.e., equity returns). To compute time-varying $\operatorname{VaR}$ at the $q$-percentile, we first estimate the following quantile regression over the bank's full weekly time series of equity returns $(X)$, requiring a minimum of 260 observations:

$$
X_{i t}=\alpha_{i}+\beta_{i} M_{t-1}+\varepsilon_{i t} .
$$

$M$ in (4) is a vector of macro state variables including: (1) VIX, which captures the implied volatility of the S\&P 500 reported by the CBOE; (2) Liquidity Spread, defined as the difference between the three-month general collateral repo rate and the three-month bill rate. Liquidity Spread is a proxy for short-term liquidity risk in market. We obtain the repo rates from Bloomberg and the bill rates from the Federal Bank of New York; (3) The change in the three-month T-Bill rate $(\Delta 3 T$-Bill $)$, as it predicts the tails of the distribution better in the financial sector than the level; (4) $\Delta$ Yield Curve Slope, measured as the yield spread between the 10-year Treasury rate and the three-month rate; (5) $\Delta$ Credit Spread, defined as change in the spread between BAA-rated bonds and the Treasury rate with the same 10-year

\footnotetext{
${ }^{19}$ In an earlier version of this paper, we document that $D E L R$ is associated with the existence of loss overhang, and that the impact of overhang on recognized loan losses is magnified during downturns. As discussed earlier, we provide evidence that DELR is associated with higher financing frictions. Bushman and Williams [2012] show that DELR is associated with increased risk-shifting behavior and that this behavior is more pronounced for banks with lower capital levels.
} 
maturity; (6) The weekly value weighted equity market return ( $\left.\operatorname{Ret}_{M r k t}\right)$; and (7) the weekly real estate (SIC code 65-66) sector return in excess of the market return ( Ret $_{\text {Estate }}$ ). The three-month T-Bill, 10-year Treasury, and spread between BAA-rated bonds and Treasuries are obtained from the Federal Reserve. ${ }^{20}$ The market returns are from CRSP.

Conditional weekly time-varying $\mathrm{VaR}$ at the q-percentile is computed as follows, where the coefficients are the estimates from equation (4), and $M$ are the realized values of the macro-conditioning variables at $t-1$ :

$$
\operatorname{VaR}_{q \%, t}^{i}=\hat{\alpha}^{i}+\hat{\beta}^{i} M_{t-1} .
$$

Finally, we roll the weekly estimated values of VaR into bank-quarter measures by summing the quarter's weekly VaR estimates. Our fundamental measure of the downside risk of the market value of equity is VaR measured at the $1^{\text {st }}$ percentile. More negative values of $\mathrm{VaR}$ indicate greater downside risk.

As a secondary statistic of the shape of the future distribution over changes in the market value of equity, we also estimate the skewness, Skew, computed as:

$$
\text { Skew }=\frac{\left(\left(V a R_{50 \%}-V a R_{1 \%}\right)-\left(V a R_{99 \%}-V a R_{50 \%}\right)\right)}{\left(V a R_{99 \%}-V a R_{1 \%}\right)},
$$

where again $V a R_{q} \%$ is the $V a R$ estimate from equation (5) at the $q^{\text {th }}$ percentile. Skew captures the relative differences in the length of the left and right tail of the distribution. Positive (negative) values of Skew indicate that the left of tail the distribution is longer (shorter) than the right tail.

We estimate the effects of DELR on the downside risk of the individual bank using the following specification:

$$
\operatorname{VaR}_{t}\left(\text { Skew }_{t}\right)=\delta_{0}+\delta_{1} D E L R_{t-1}+\text { Controls }+F E+\varepsilon_{t},
$$

where our downside risk measures are VaR and Skew. As controls we include the following which were defined earlier and in the appendix: Trading, Commercial, Consumer, Real Estate, Mismatch, Deposits, Revenue Mix, Capital, $\beta_{\text {Mrkt }}$, $\sigma_{e}$, Size, MTB, Illiquid, Return, LoanGrowth. We also include the unemployment rate, \% UnEmploy, and time fixed effects.

Table 3 reports results from estimating (7) in a pooled OLS regression, and separately for boom and bust periods. Focusing first on $V a R$, the coefficient on DELR in the pooled regression is -0.0435 with a $p$-value $<0.05$, indicating that high DELR banks for the same $1 \%$ probability expect a relatively larger decrease in the market value of equity than do low DELR banks.

\footnotetext{
${ }^{20}$ These macro variables, $M$, serve as time-varying conditioning variables conjectured to shift the conditional mean and the conditional volatility of the risk measures. Note that different firms can load on these risk factors in different directions, so that particular correlations of the risk measures across firms or correlations of the different risk measures for the same firm are not imposed by construction (Adrian and Brunnermeier [2011]).
} 


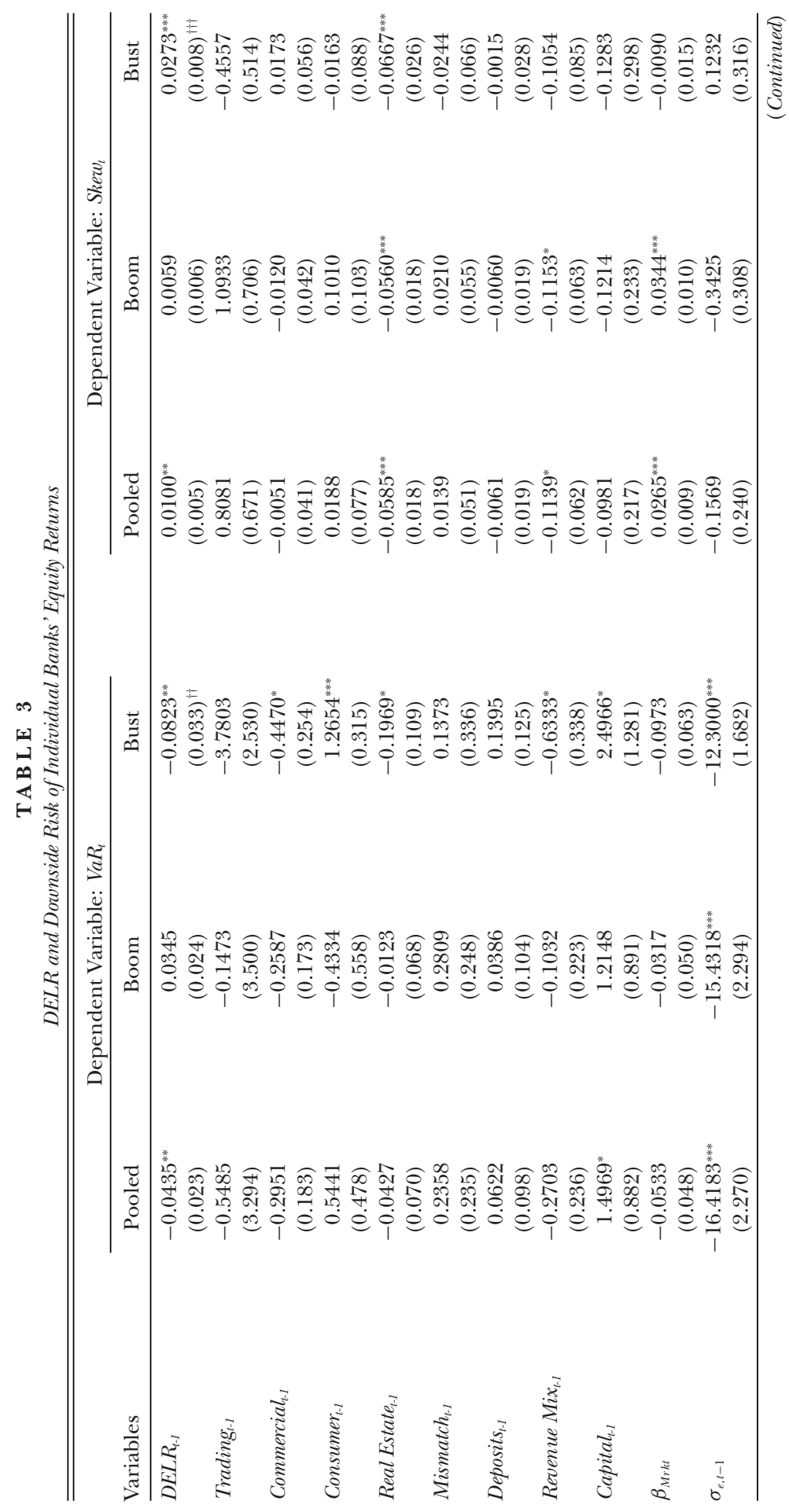




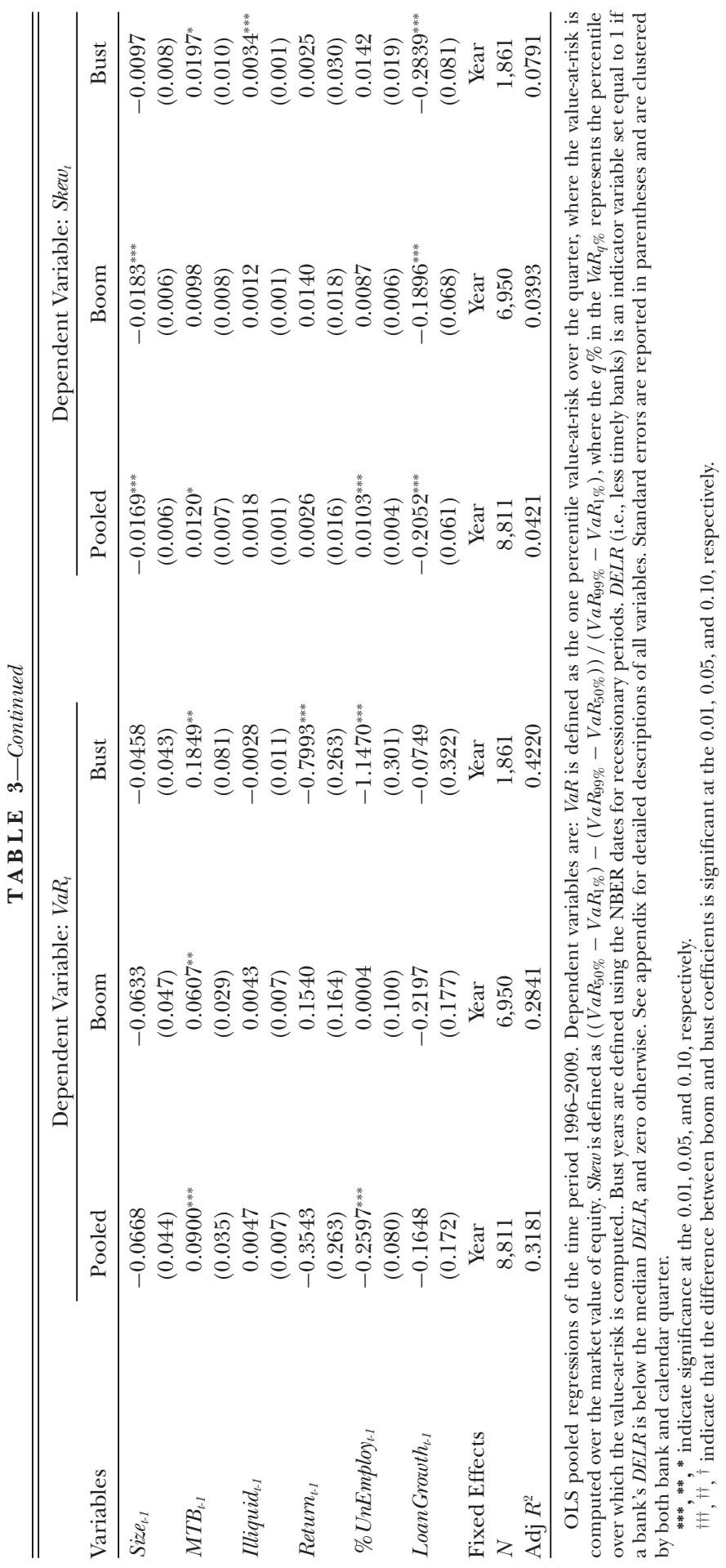


Next we estimate the effect of DELR on downside risk separately for bust periods (i.e., NBER-defined recession quarters) and boom periods (i.e., nonrecession quarters). In table 3 , column 3 , we see that, for the boom period, the coefficient on DELR (0.034) is not statistically different from zero. However, for the bust period (column 4), the DELR coefficient (-0.0823) is statistically significant ( $p$-value $<0.05$ ). Further, the difference in the coefficients across boom and bust periods is significantly different ( $p$-value $<$ $0.05)$, consistent with the effects of DELR on individual banks' downside risk being greater during bust periods compared to boom periods.

We find similar results for Skew. In table 3, column 5, the coefficient on $D E L R$ is 0.0100 ( $p$-value $<0.05)$, indicating that high DELR banks have more left-skewed distributions compared to low DELR banks. In table 3, column 6, we see that the boom period coefficient on DELR (0.0059) is not statistically different from zero, while the bust period coefficient $(0.0273)$ is statistically significant ( $p$-value $<0.01)$. Further, columns 6 and 7 reveal that the DELR effect is concentrated in the bust period and significantly different from the boom period coefficient $(p$-value $<0.01)$.

Taken together, the results in table 3 show that higher DELR is associated with significantly higher downside risk and that the effect is concentrated in recessionary periods. We find that high $D E L R$ banks exhibit significantly greater tail risk than low DELR banks in bust periods, but find no difference between high and low DELR banks in boom periods. These analyses complement and extend the results in Beatty and Liao [2011] showing that $D E L R$ leads banks to curtail lending during recessions by establishing a significant association between DELR and tail risk vulnerability of individual banks. Further, the analyses in table 3 control for realized loan growth measured contemporaneously with DELR. Thus, the coefficient on DELR only reflects aspects of $D E L R$ that are orthogonal to loan growth. This suggests that the influence of $D E L R$ on downside risk reflects more than just shortterm reductions in loan growth. Disentangling these effects is a potentially interesting avenue for future research

\subsection{SENSITIVITY OF INDIVIDUAL BANK'S DOWNSIDE RISK TO SYSTEM DISTRESS $\left(\triangle \mathrm{CoVaR} R^{I \mid S Y S T E M}\right)$}

We next examine whether DELR increases the sensitivity of an individual bank's downside risk to distress of the entire banking system. To implement this analysis, we estimate the VaR of each individual bank conditional on the banking system being in distress and also conditional on the system at its normal state. Specifically, we define CoVaR ${ }^{\text {system|i }}$ as VaR of bank $i$ conditional on the state of the banking system, and estimate the following two quantile regressions:

$$
\begin{gathered}
X_{t}^{\text {system }}=\gamma_{1}^{s}+\gamma_{2}^{s} M_{t-1}+\varepsilon_{t}^{\text {system }}, \\
X_{t}^{i}=\alpha^{i \mid \text { system }}+\delta^{i \mid \text { system }} X_{t}^{\text {system }}+\beta^{i \mid \text { system }} M_{t-1}+\varepsilon_{t}^{i} .
\end{gathered}
$$


Here, $X^{i}$ is bank $i$ s weekly stock return, $X^{\text {system }}$ is the value-weighted return from the portfolio of all banks in the economy (excluding bank $i$ ), and $M$ is the vector of macro-conditioning variables defined above. Equation (8) is analogous to equation (4), except now we are computing a timevarying $V a R$ for the aggregate banking system. Equation (9) extends equation (4) by conditioning on equity returns of the banking system $\left(X^{\text {system }}\right)$.

We estimate (8) and (9), where (8) is estimated at both $q \%=1 \%$ and $50 \%$, and (9) at $q \%=1 \%$. Using the predicted values from (8) and (9), we specify

$$
\begin{aligned}
& \operatorname{VaR} R_{q \%, t}^{s y s t e m}=\hat{\gamma}_{1}^{s}+\hat{\gamma}_{2}^{s} M_{t-1} \\
& \operatorname{CoVaR} R_{1 \%, t}^{i \mid \text { system }}=\hat{\alpha}^{i \mid \text { system }}+\hat{\delta}^{i \mid \text { system }} \operatorname{VaR}_{1 \% \text { or } 50 \%, t}^{\text {system }}+\hat{\beta}^{i \mid \text { system }} M_{t-1} .
\end{aligned}
$$

CoVaR $R_{1 \%, t}^{i \mid s y s t e m}$, equation (11), is bank $i$,s time $t$ VaR at $q \%=1 \%$, conditional on the $\operatorname{VaR}$ of the banking system being at either the $1 \%$ or $50 \%$ quantile. To capture the sensitivity of bank $i$ 's conditional $V a R_{1 \%}$ to system-wide financial turmoil, we compute

$$
\begin{aligned}
& \Delta \mathrm{CoVaR} R_{t}^{i \mid \text { system }}=\mathrm{CoVaR} R_{t}^{i \mid \text { system }=V a R_{1 \%}}-\mathrm{CoVaR} R_{t}^{i \mid \text { system }=\operatorname{VaR} R_{50 \%}} \\
& =\hat{\alpha}^{i \mid \text { system }}+\hat{\delta}^{i \mid \text { system }}\left(\operatorname{VaR}_{1 \%, t}^{\text {system }}-\operatorname{VaR}_{50 \%, t}^{\text {system }}\right)+\hat{\beta}^{i \mid \text { system }} M_{t-1} .
\end{aligned}
$$

CoVaR ${ }^{i \mid s y s t e m}$ captures the marginal contribution of the banking system to the downside risk of bank $i$. Following Adrian and Brunnermeier [2011], we sum the weekly $\mathrm{CoVaR} \mathrm{R}^{i \mid s y s t e m}$ to a quarterly measure. More negative values of CoVaR $R^{i \mid s y s t e m}$ indicate that the bank's downside risk is more affected by the system moving from "normal" to "distressed" states, suggesting that an individual bank is more vulnerable to system-wide events.

Table 4, column 2, reports a DELR coefficient of -0.0138 in a pooled specification, where this coefficient is not statistically different from zero. However, when we split between boom and bust periods, we find that the expected downside risk of high DELR banks is more vulnerable to systemic events during economic downturns. Specifically, in table 4 , the DELR coefficient in the bust period is -0.0609 and statistically significant ( $p$-value $<$ 0.05 ), while for the boom periods the DELR coefficient is -0.0025 and statistically insignificant. Moreover, the bust period coefficients are significantly larger than the boom period coefficients $(p$-value $<0.05)$.

In untabulated results, we show that our DELR results are robust to an alternative measure of the relation between performance of the system and the risk of the bank. Specifically, we follow Acharya et al. [2010] and compute the marginal expected shortfall (MES) of the bank. MES captures the correlation between a bank's equity returns and market equity returns on the days where the market return is in the bottom $5 \%$ for the quarter. That is, it measures the extent to which an individual bank's returns are low when the overall (banking) market returns are low. 
TA B L E 4

Sensitivity of Individual Banks' Tail Risk to Systemic Events

\begin{tabular}{|c|c|c|c|}
\hline \multirow[b]{2}{*}{ Variables } & \multicolumn{3}{|c|}{ Dependent Variable: $\Delta C o V a R_{t}^{i \mid s y s t e m}$} \\
\hline & Pooled & Boom & Bust \\
\hline$D E L R_{t-1}$ & $\begin{array}{c}-0.0138 \\
(0.015)\end{array}$ & $\begin{array}{c}-0.0025 \\
(0.014)\end{array}$ & $\begin{array}{c}-0.0609^{* *} \\
(0.026)^{\dagger \dagger}\end{array}$ \\
\hline Trading $_{t-1}$ & $\begin{array}{c}-2.0555 \\
(1.622)\end{array}$ & $\begin{array}{c}-2.2966 \\
(1.528)\end{array}$ & $\begin{array}{r}-2.3111 \\
(2.167)\end{array}$ \\
\hline Commercial $_{t-1}$ & $\begin{array}{c}0.0832 \\
(0.136)\end{array}$ & $\begin{array}{c}0.0439 \\
(0.127)\end{array}$ & $\begin{array}{c}0.2170 \\
(0.175)\end{array}$ \\
\hline Consumer $_{t-1}$ & $\begin{array}{c}0.1158 \\
(0.350)\end{array}$ & $\begin{array}{c}-0.2300 \\
(0.342)\end{array}$ & $\begin{array}{l}0.6816^{*} \\
(0.389)\end{array}$ \\
\hline Real Estate t- $_{1}$ & $\begin{array}{c}-0.0624 \\
(0.057)\end{array}$ & $\begin{array}{r}-0.0437 \\
(0.054)\end{array}$ & $\begin{array}{c}-0.1556^{*} \\
(0.080)\end{array}$ \\
\hline Mismatch $_{t-1}$ & $\begin{array}{c}-0.1783 \\
(0.188)\end{array}$ & $\begin{array}{c}-0.1185 \\
(0.172)\end{array}$ & $\begin{array}{c}-0.3292 \\
(0.261)\end{array}$ \\
\hline Deposits $_{t-1}$ & $\begin{array}{l}0.1366^{* *} \\
(0.057)\end{array}$ & $\begin{array}{l}0.1230^{* *} \\
(0.052)\end{array}$ & $\begin{array}{c}0.1556^{*} \\
(0.084)\end{array}$ \\
\hline Revenue Mix $x_{t-1}$ & $\begin{array}{c}-0.0542 \\
(0.185)\end{array}$ & $\begin{array}{c}0.0425 \\
(0.169)\end{array}$ & $\begin{array}{c}-0.1536 \\
(0.331)\end{array}$ \\
\hline Capital $_{t-1}$ & $\begin{array}{r}0.3037 \\
(0.618)\end{array}$ & $\begin{array}{c}0.1375 \\
(0.557)\end{array}$ & $\begin{array}{c}0.6313 \\
(1.028)\end{array}$ \\
\hline$\beta_{M r k t}$ & $\begin{array}{c}-0.0417^{*} \\
(0.023)\end{array}$ & $\begin{array}{c}-0.0193 \\
(0.019)\end{array}$ & $\begin{array}{c}-0.1097^{\text {*** }} \\
(0.041)\end{array}$ \\
\hline$\sigma_{e, t-1}$ & $\begin{array}{c}-4.8013^{* * *} \\
(1.203)\end{array}$ & $\begin{array}{c}-2.9442^{* * *} \\
(1.101)\end{array}$ & $\begin{array}{c}-2.6375^{* *} \\
(1.060)\end{array}$ \\
\hline Size $_{t-1}$ & $\begin{array}{c}-0.1176^{* * *} \\
(0.015)\end{array}$ & $\begin{array}{c}-0.1049^{* * *} \\
(0.015)\end{array}$ & $\begin{array}{c}-0.1355^{* * *} \\
(0.020)\end{array}$ \\
\hline$M T B_{t-1}$ & $\begin{array}{r}-0.0131 \\
(0.022)\end{array}$ & $\begin{array}{c}-0.0255 \\
(0.018)\end{array}$ & $\begin{array}{c}0.0065 \\
(0.043)\end{array}$ \\
\hline Illiquid $_{t-1}$ & $\begin{array}{l}0.0149^{* * *} \\
(0.005)\end{array}$ & $\begin{array}{l}0.0136^{* * *} \\
(0.005)\end{array}$ & $\begin{array}{c}0.0097 \\
(0.009)\end{array}$ \\
\hline Return $_{t-1}$ & $\begin{array}{c}-0.4410^{* *} \\
(0.208)\end{array}$ & $\begin{array}{c}-0.0769 \\
(0.053)\end{array}$ & $\begin{array}{c}-0.6849^{* * *} \\
(0.196)\end{array}$ \\
\hline$\%$ UnEmploy ${ }_{t-1}$ & $\begin{array}{c}-0.1908^{* * * *} \\
(0.063)\end{array}$ & $\begin{array}{c}0.0200 \\
(0.056)\end{array}$ & $\begin{array}{c}-0.9241^{* * *} \\
(0.165)\end{array}$ \\
\hline LoanGrowth $_{t-1}$ & $\begin{array}{c}-0.1262 \\
(0.115)\end{array}$ & $\begin{array}{r}-0.1471 \\
(0.109)\end{array}$ & $\begin{array}{c}0.0450 \\
(0.278)\end{array}$ \\
\hline Fixed Effects & Year & Year & Year \\
\hline $\begin{array}{l}N \\
\text { Adj } R^{2}\end{array}$ & $\begin{array}{c}8,371 \\
0.3790\end{array}$ & $\begin{array}{c}6,950 \\
0.3892\end{array}$ & $\begin{array}{c}1,861 \\
0.4120\end{array}$ \\
\hline
\end{tabular}

OLS pooled regressions of the time period 1996-2009, where $\Delta$ CoVaR ${ }^{i \mid s y s t e m}$ is the dependent variable and is defined as the sum of the system's weekly contribution to either the bank's VaR over the market value of assets or equity for the quarter. DELR (i.e., less timely banks) is an indicator variable set equal to 1 if a bank's DELR is below the median DELR, and zero otherwise. Bust years are defined using the NBER dates for recessionary periods. See the appendix for detailed descriptions of all variables. Year-fixed effects are included in all regressions and standard errors are reported in parentheses and are clustered by both bank and calendar quarter.

${ }^{* * *},{ }^{* *},{ }^{*}$ indicate significance at the $0.01,0.05$, and 0.10 , respectively.

$\mathrm{i \dagger \dagger},{ }^{\dagger},{ }^{\dagger}$ indicate that the difference between boom and bust coefficients is significant at the $0.01,0.05$ and 0.10 , respectively. 


\subsection{DELR AND DOWNSIDE RISK: THE EFFECT OF CAPITAL LEVELS}

In this paper, we argue that DELR can degrade bank transparency and generate expected loss overhangs. Higher opacity-induced financing frictions combined with loss overhangs can generate capital inadequacy concerns that expose the bank to downside risk from a variety of sources. Further, reduced transparency can increase opportunities for risk-shifting activities, where incentives for such activities are higher when a bank faces capital inadequacy concerns. Because we theorize that capital inadequacy concerns combined with lower transparency (e.g., financing frictions, riskshifting opportunities) underpin the influence of DELR on tail risk vulnerability, it is important that we investigate the extent to which the connection between DELR and downside risk is magnified for banks with lower regulatory capital levels.

To perform this analysis, each quarter we rank all banks based on their tier-1 capital levels. We then partition banks into quintiles and define banks in the lowest quintile of tier-1 capital levels as low capital banks, and banks in the top four quintiles as high capital banks. The low capital partitions have average tier-1 capital of $7.8 \%$, where the average for high capital banks is $11.5 \%$. We then re-run our $\mathrm{VaR}$ and $\mathrm{CoVaR}{ }^{i \mid s y s t e m}$ analyses separately for low and high capital firms. We only focus on bust periods as it is shown in tables 3 and 4 that there is no relation between DELR and either VaR or CoVaR ${ }^{\text {system|i }}$ in boom periods. The results of this analysis are reported in table 5 .

Focusing first on $V a R$, we see that the coefficient on DELR for the low capital partition of -0.123 ( $p$-value $<0.01)$ is significantly different $(p$-value $<$ 0.01 ) from the coefficient in the high capital partition of -0.0587 . When the dependent variable is $\mathrm{CoVaR}^{i \mid s y s t e m}$, we see that the coefficient on DELR for the low capital partition of -0.111 ( $p$-value $<0.01$ ) is significantly different $(p$-value $<0.05)$ from the coefficient in the high capital partition of -0.04 . These results are consistent with $D E L R$-driven capital inadequacy concerns, operating in conjunction with low transparency, making banks more vulnerable to downside risk during recessions. Where Beatty and Liao [2011] focus on how DELR conditions the sensitivity of current lending decisions to bank capital, we find that a bank's capital level conditions the association between DELR and downside risk, where this association is significantly higher for banks with lower regulatory capital levels.

\section{$4.4 D E L R$ AND THE CONTRIBUTION OF INDIVIDUAL BANKS TO SYSTEMIC RISK: $\triangle$ CoVaR $R_{q}^{\text {systemli }}$}

Our final analysis examines how DELR conditions the influence that individual banks have in exacerbating the future expected downside risk of the banking system. To examine the impact of an individual bank on the system, we define $\mathrm{CoVaR}^{\text {system|i }}$ as $V a R_{1 \%}^{\text {system }}$ of the banking system conditional on the VaR of bank $i$. The difference between CoVaR ${ }^{\text {system } \mid i}$ conditional on bank $i$ being in distress (e.g., bank $i$ outcome $=V a R_{q=1 \%}^{i}$ ) and CoVaR ${ }^{\text {system } \mid i}$ 


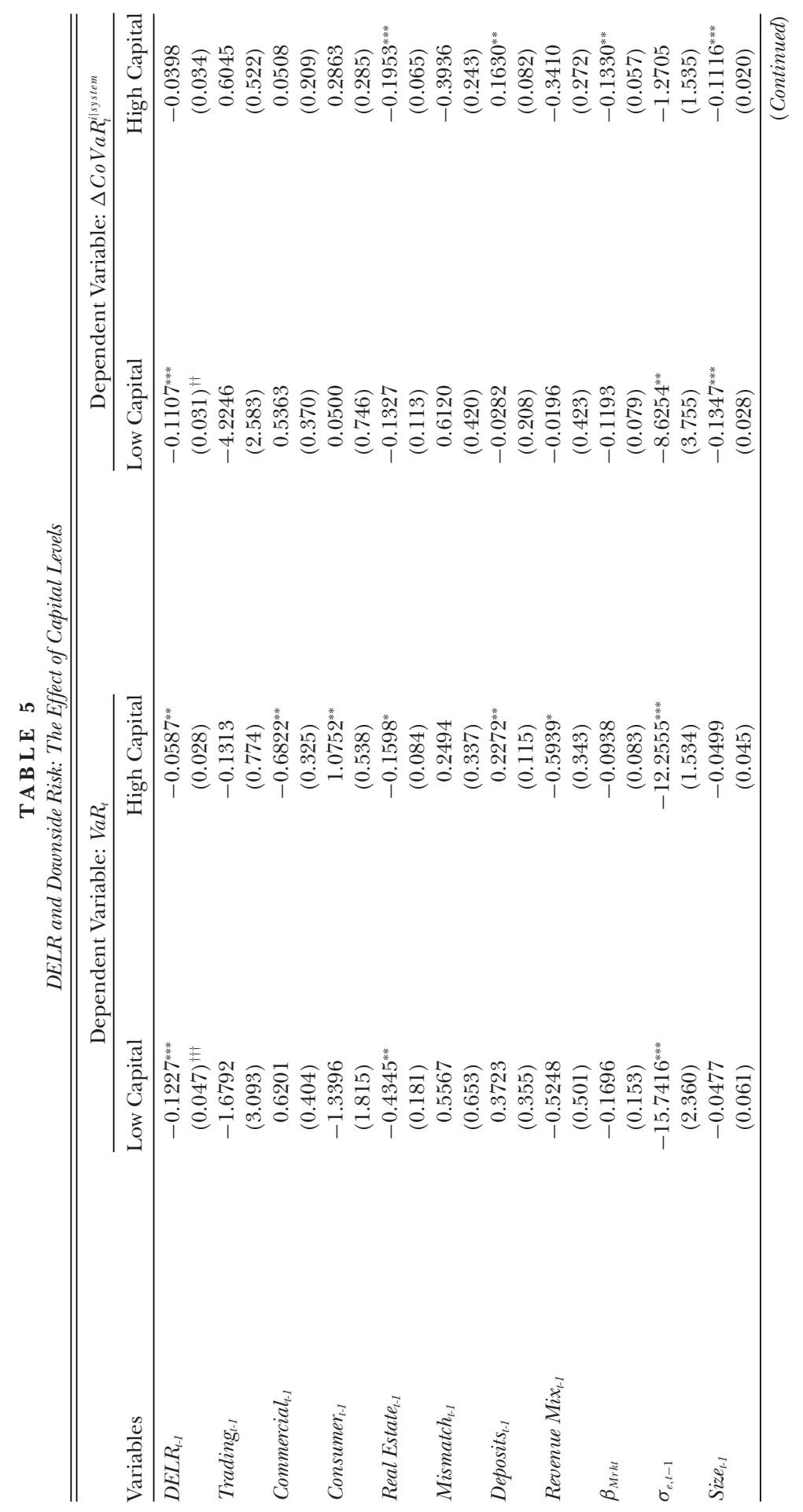




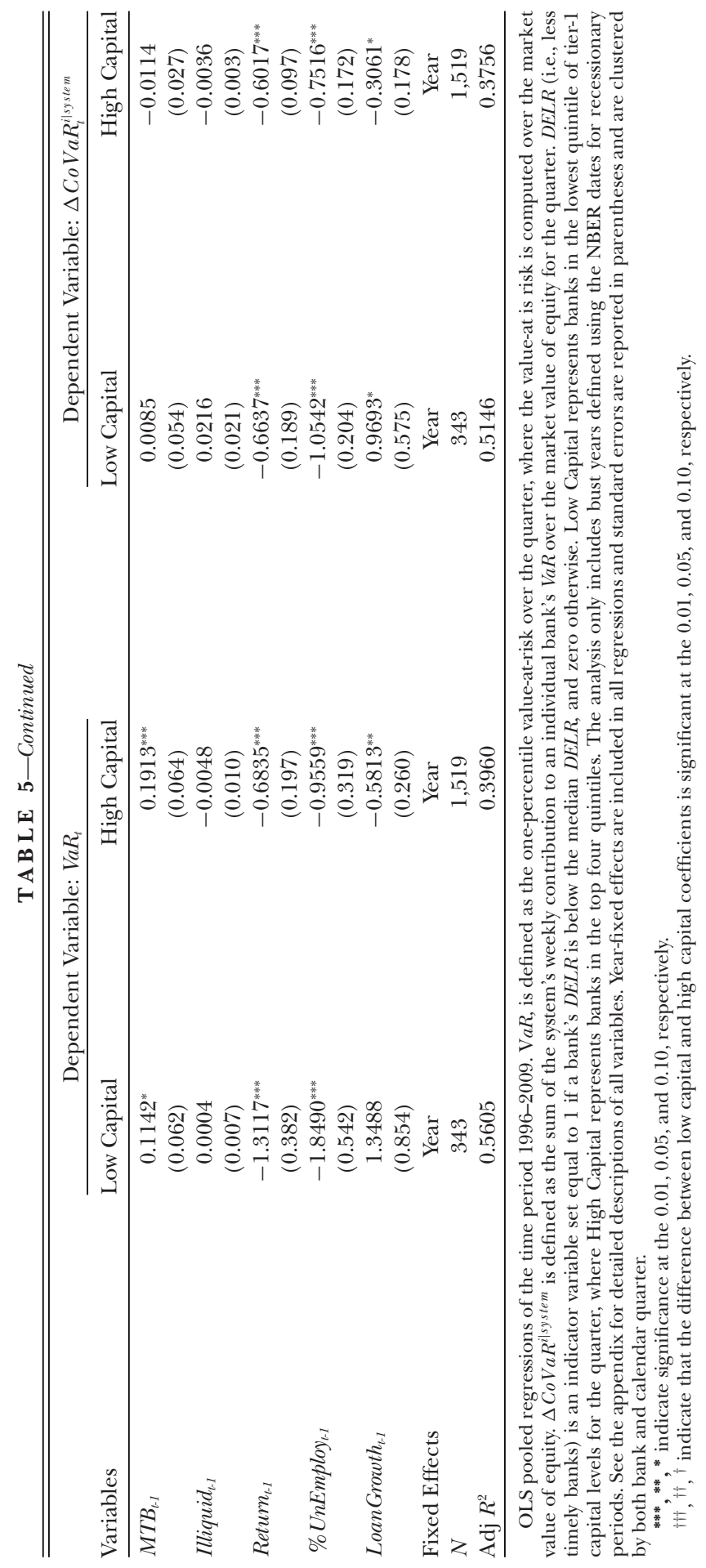


conditional on the median or "normal" state of bank $i$ (bank $i$ outcome $=$ $\left.\operatorname{VaR}_{q=50 \%}^{i}\right)$, CoVaR ${ }^{i \mid s y s t e m}$, captures the marginal contribution of a particular institution to the overall downside risk to the banking system or systemic risk (Adrian and Brunnermeier [2011]). To compute CoVaR ${ }^{i \mid s y s t e m}$ we estimate the following quantile regressions equations again using weekly data:

$$
\begin{gathered}
X_{t}^{i}=\gamma_{1}^{i}+\gamma_{2}^{i} M_{t-1}+\varepsilon_{t}^{i}, \\
X_{t}^{\text {system }}=\alpha^{\text {system } \mid i}+\delta^{\text {system } \mid i} X_{t}^{i}+\beta^{\text {system } \mid i} M_{t-1}+\varepsilon_{t}^{\text {system } \mid i} .
\end{gathered}
$$

We then compute the predicted values

$$
\begin{aligned}
& \operatorname{VaR} R_{q, t}^{i}=\hat{\gamma}_{1}^{i}+\hat{\gamma}_{2}^{i} M_{t-1}, \\
& \operatorname{CoVaR} R_{1 \%, t}^{\text {system } \mid i}=\hat{\alpha}^{\text {system } \mid i}+\hat{\delta}^{\text {system } \mid i} \operatorname{VaR}_{1 \% \text { or } 50 \%, t}^{i}+\hat{\beta}^{\text {system } \mid i} M_{t-1} .
\end{aligned}
$$

To capture the effects of the individual bank on the system when moving from a normal state to distressed state, we compute $\Delta C o V a R_{1 \%}^{s y s t e m \mid i}$ as:

$$
\begin{aligned}
& \Delta \operatorname{CoVaR} R_{t}^{\text {system } \mid i}=\operatorname{CoVaR} R_{t}^{\text {system } \mid i=V_{a} R_{1 \%}}-C_{o V a R} R_{t}^{\text {system } \mid i=V a R_{50 \%}} \\
& =\hat{\alpha}^{\text {system } \mid i}+\hat{\delta}^{\text {system } \mid i}\left(\operatorname{VaR}_{1 \%, t}^{i}-\operatorname{VaR}_{50 \%, t}^{i}\right)+\hat{\beta}^{\text {system } \mid i} M_{t-1} .
\end{aligned}
$$

We again sum weekly $\Delta C o V a R_{1 \%}^{\text {system|i }}$ to obtain quarterly measures for the distributions over equity returns, $\Delta C o V a R_{1 \% t}^{\text {system } \mid i}$. More negative values indicate that a move of bank $i$ from a normal state to a "distressed" state produces a larger marginal contribution to the downside risk of the equity returns of the banking system.

Table 6 reports that the coefficient on DELR in the pooled specification is 0.0122 ( $p$-value $<0.01$ ). After splitting between boom and bust periods, table 6 reports that the coefficient on DELR is negative in both the boom and bust periods $(-0.01$ and -0.021 , respectively), where the difference between the boom period and bust period coefficients is statistically significant $(p$-value $<0.01)$.

Taken together, the results from table 6 suggest that high DELR banks contribute more to systemic risk and the effect is greater during economic downturns. Consistent with high DELR banks increasing systemic risk, table 6 shows that banks with higher DELR contribute more to the risk of severe drops in equity values for the aggregate banking sector. We theorize that, when a group of banks all delay loss recognition in good times, all group members will simultaneously face the consequences of increased capital inadequacy, low transparency, and investor uncertainty during a downturn creating systemic effects from banks acting as part of a herd.

\subsection{ADDITIONAL TESTS AND ROBUSTNESS}

In this section, we report results from performing a number of additional tests to establish the robustness of our results. 
TA B L E 6

DELR and the Contribution of Individual Banks to Systemic Risk

\begin{tabular}{|c|c|c|c|}
\hline \multirow[b]{2}{*}{ Variables } & \multicolumn{3}{|c|}{ Dependent Variable: $\Delta C o V a R_{t}^{\text {system } \mid i}$} \\
\hline & Pooled & Boom & Bust \\
\hline$D E L R_{t-1}$ & $\begin{array}{c}-0.0122^{* * *} \\
(0.004)\end{array}$ & $\begin{array}{c}-0.0101^{* *} \\
(0.005)\end{array}$ & $\begin{array}{r}-0.0209^{* * *} \\
(0.007)^{\dagger \dagger \dagger}\end{array}$ \\
\hline Trading $_{t-1}$ & $\begin{array}{c}0.4656 \\
(0.699)\end{array}$ & $\begin{array}{c}0.4753 \\
(0.673)\end{array}$ & $\begin{array}{c}0.2271 \\
(0.792)\end{array}$ \\
\hline Commercial $_{t-1}$ & $\begin{array}{c}-0.0799 \\
(0.050)\end{array}$ & $\begin{array}{c}-0.0676 \\
(0.050)\end{array}$ & $\begin{array}{c}-0.1119^{*} \\
(0.060)\end{array}$ \\
\hline Consumer $_{t-1}$ & $\begin{array}{c}0.0511 \\
(0.101)\end{array}$ & $\begin{array}{r}-0.0427 \\
(0.123)\end{array}$ & $\begin{array}{c}0.1311 \\
(0.094)\end{array}$ \\
\hline Real Estate $t_{t-1}$ & $\begin{array}{c}0.0313 \\
(0.021)\end{array}$ & $\begin{array}{c}0.0335 \\
(0.020)\end{array}$ & $\begin{array}{c}0.0218 \\
(0.025)\end{array}$ \\
\hline Mismatch $_{t-1}$ & $\begin{array}{c}-0.0934 \\
(0.076)\end{array}$ & $\begin{array}{r}-0.0962 \\
(0.077)\end{array}$ & $\begin{array}{c}-0.0980 \\
(0.084)\end{array}$ \\
\hline Deposits $_{t-1}$ & $\begin{array}{l}0.0451^{\text {** }} \\
(0.023)\end{array}$ & $\begin{array}{c}0.0424^{*} \\
(0.023)\end{array}$ & $\begin{array}{l}0.0554^{*} \\
(0.031)\end{array}$ \\
\hline Revenue Mix $x_{t-1}$ & $\begin{array}{c}0.0833 \\
(0.066)\end{array}$ & $\begin{array}{c}0.0989 \\
(0.067)\end{array}$ & $\begin{array}{r}0.0707 \\
(0.089)\end{array}$ \\
\hline Capital $_{t-1}$ & $\begin{array}{c}-0.1250 \\
(0.235)\end{array}$ & $\begin{array}{c}-0.1993 \\
(0.241)\end{array}$ & $\begin{array}{c}0.0591 \\
(0.295)\end{array}$ \\
\hline$\beta_{M r k t}$ & $\begin{array}{c}-0.0244^{* * *} \\
(0.007)\end{array}$ & $\begin{array}{c}-0.0183^{* *} \\
(0.007)\end{array}$ & $\begin{array}{c}-0.0456^{\text {*** }} \\
(0.012)\end{array}$ \\
\hline$\sigma_{e, t-1}$ & $\begin{array}{c}-0.8750^{* * *} \\
(0.302)\end{array}$ & $\begin{array}{c}-0.6935^{* *} \\
(0.335)\end{array}$ & $\begin{array}{c}-0.4812 \\
(0.342)\end{array}$ \\
\hline Size $_{t-1}$ & $\begin{array}{c}-0.0118^{*} \\
(0.006)\end{array}$ & $\begin{array}{c}-0.0113^{*} \\
(0.006)\end{array}$ & $\begin{array}{c}-0.0099 \\
(0.008)\end{array}$ \\
\hline$M T B_{t-1}$ & $\begin{array}{c}-0.0223^{* * *} \\
(0.008)\end{array}$ & $\begin{array}{c}-0.0239^{* * * *} \\
(0.008)\end{array}$ & $\begin{array}{c}-0.0194 \\
(0.015)\end{array}$ \\
\hline Illiquid $_{t-1}$ & $\begin{array}{l}0.0045^{\text {**** }} \\
(0.001)\end{array}$ & $\begin{array}{l}0.0045^{\text {**** }} \\
(0.001)\end{array}$ & $\begin{array}{c}0.0037 \\
(0.002)\end{array}$ \\
\hline Return $_{t-1}$ & $\begin{array}{c}-0.0492 \\
(0.032)\end{array}$ & $\begin{array}{c}0.0046 \\
(0.026)\end{array}$ & $\begin{array}{c}-0.0934^{* * *} \\
(0.035)\end{array}$ \\
\hline$\%$ UnEmploy ${ }_{t-1}$ & $\begin{array}{c}-0.0366^{* * * *} \\
(0.011)\end{array}$ & $\begin{array}{c}0.0004 \\
(0.015)\end{array}$ & $\begin{array}{c}-0.1194^{\text {*** }} \\
(0.029)\end{array}$ \\
\hline LoanGrowth $_{t-1}$ & $\begin{array}{c}-0.0232 \\
(0.053)\end{array}$ & $\begin{array}{c}-0.0177 \\
(0.051)\end{array}$ & $\begin{array}{c}-0.0390 \\
(0.099)\end{array}$ \\
\hline Fixed Effects & Year & Year & Year \\
\hline$N$ & 8,371 & 6,860 & 1,804 \\
\hline $\operatorname{Adj} R^{2}$ & 0.1969 & 0.1998 & 0.1786 \\
\hline
\end{tabular}

OLS pooled regressions of the time period 1996-2009, where $\Delta \mathrm{CoVaR}^{\text {system|i }}$ is the dependent variable and is defined as the sum of the firm's weekly contribution to systemic risk over the quarter for the market value of equity. DELR (i.e., less timely banks) is an indicator variable set equal to 1 if a bank's DELR is below the median DELR, and zero otherwise. Bust years are defined using the NBER dates for recessionary periods. See the appendix for detailed descriptions of all variables. Year-fixed effects are included in all regressions and standard errors are reported in parentheses and are clustered by both bank and calendar quarter.

${ }^{* * *}, * *,{ }^{*}$ indicate significance at the $0.01,0.05$, and 0.10 , respectively.

$\mathrm{it \dagger},{ }^{\prime} \dagger,{ }^{\dagger}$ indicate that the difference between boom and bust coefficients is significant at the $0.01,0.05$, and 0.10 , respectively. 
4.5.1. CAMELS, Lagged Values of the Dependent Variable, and Firm Fixed Effects. An alternative explanation for our reported results is that the variation in DELR arises from variation in regulator-imposed loss recognition (e.g., for weaker vs. stronger banks). To control for such differences, we include proxies for the regulatory CAMELS ratios for the banks. As these ratings are not released to the public, we follow Duchin and Sosyura [2014] and include proxies for CAMELS ratings ${ }^{21}$ : $\mathbf{C}$ (tier 1 capital), $\mathbf{A}$ (nonperforming loans/total loans), M\&E (ROA), ${ }^{22} \mathbf{L}$ (cash/deposits), $\mathbf{S}$ ([ [shortterm assets-short-term liabilities]/total assets). We also include lagged values of the dependent variable to correct for endogenous risk persistence. For brevity, we report the coefficients on DELR and the lagged risk measures in table 7 for both the boom and bust subsamples. Table 7 shows that across all downside risk measures the coefficient on DELR continues to be significantly negative in bust periods, where the bust period coefficients are significantly larger than the boom period coefficients.

In untablulated results, we include bank fixed effects in addition to the lagged dependent variables and all other controls. We find that including bank fixed effects does not have a substantive effect on the DELR coefficients in any of our downside risk regressions.

4.5.2. Controlling for Differences in Managerial Ability. To rule out the possibility that DELR is simply capturing differences in managerial ability, we follow Beatty and Liao [2011] and use ROA to proxy for management quality based on DeYoung [1998]. In untabulated results, we interact our DELR variable with $R O A$ and find that all of our results are not only robust to the inclusion of $R O A$ as a main effect, but also that the coefficient on the interaction $D E L R^{*} R O A$ is not statistically significant from zero. As a second test to control for the ability of management, we also include CEO fixed effects. Despite a significant reduction in sample size, in untabulated results we find that our results are robust to the inclusion of CEO fixed effects.

4.5.3. The Distribution over Changes in Market Value of Bank Assets. While our main analyses examine risk with respect to the distribution over equity returns, Adrian and Brunnermeir [2011] focused on the distribution over changes in the market value of banks' assets. Because it is conceptually possible that the distributions over changes in asset and equity values reflect different information, we examined the robustness of our results by defining downside risk with respect to distribution over percentage changes in the market value of banks' assets. The market value of a bank's total assets

\footnotetext{
${ }^{21}$ CAMELS: Capital adequacy, Asset quality, Management, Earnings, Liquidity, Sensitivity to market risk.

${ }^{22}$ Our use of ROA to proxy for management quality follows Beatty and Liao [2011] and DeYoung [1998]. Using confidential information on CAMELS ratings, DeYoung [1998] finds that regulators' management quality assessments correlate with multiple bank characteristics, among which ROA is most highly correlated with management quality with a simple correlation of $45 \%$.
} 


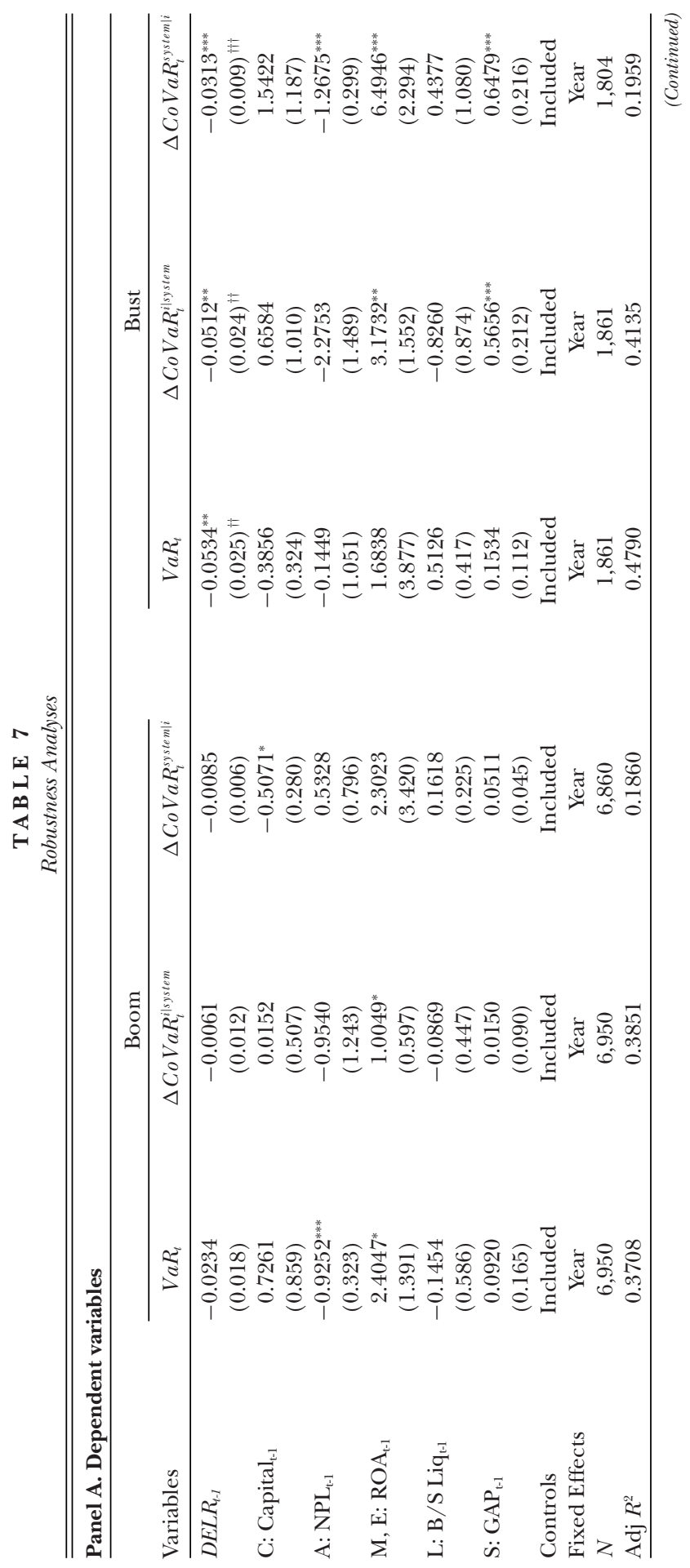




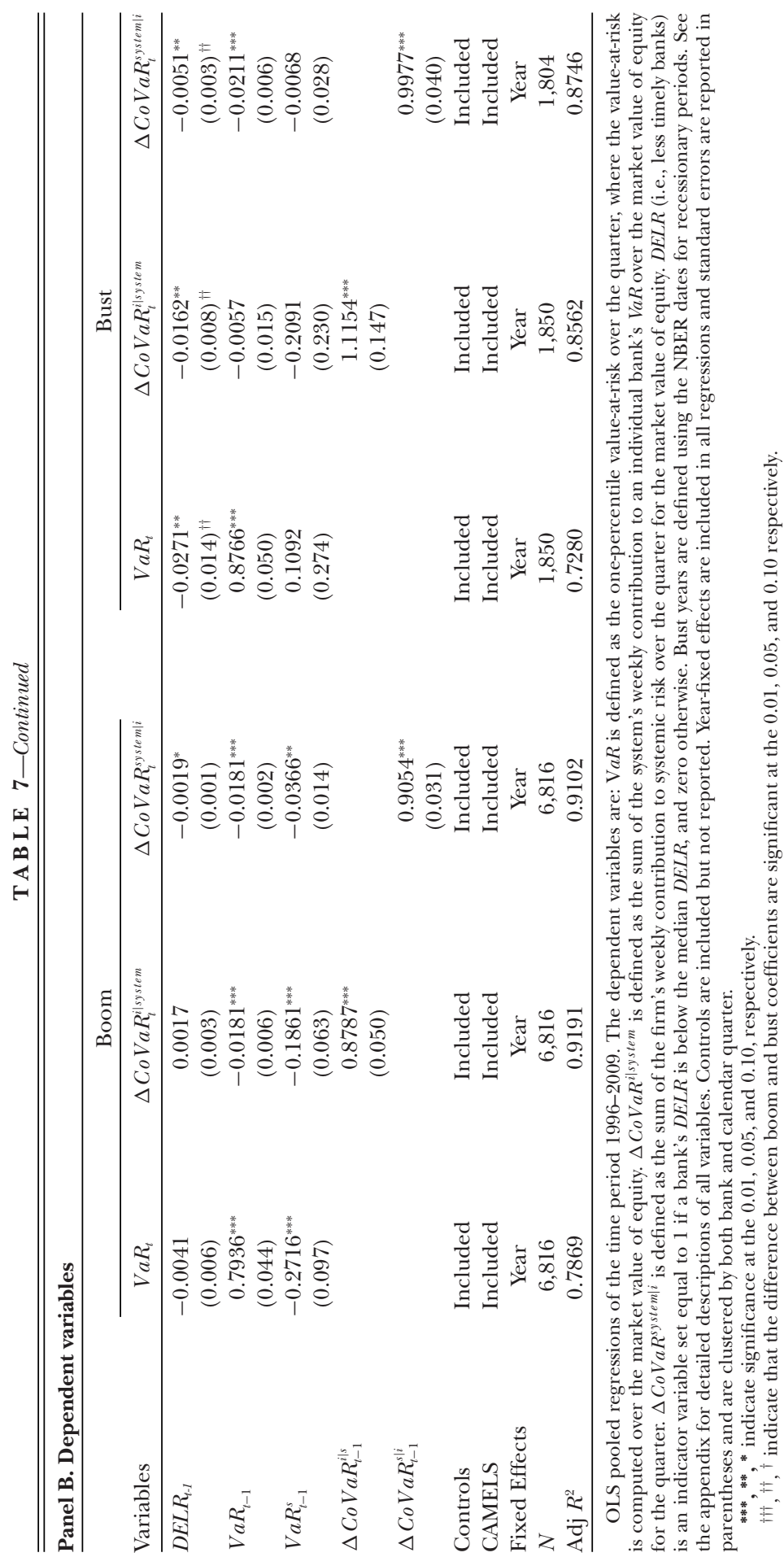


is not observable, and so we follow Adrian and Brunnermier [2011] and estimate the market value of bank assets by using balance sheet leverage ratios to de-lever the market value of banks' equity as follows:

$$
\begin{aligned}
X_{t}= & \frac{M V A_{t}-M V A_{t-1}}{M V A_{t-1}}=\frac{\left(M T B_{t} * B V A_{t}\right)-\left(M T B_{t-1}-B V A_{t-1}\right)}{M T B_{t-1} * B V A_{t-1}} \\
= & \frac{M V E_{t}}{M V E_{t-1}} *\left[\frac{B V A_{t} / B V E_{t}}{B V A_{t-1} / B V E_{t-1}}\right]-1 .
\end{aligned}
$$

$M T B$ is the weekly market to book ratio, $B V A(B V E)$ is the weekly book value of assets (equity), and $M V E$ is market value of equity. Because book value of equity and book value of assets are only reported on a quarterly basis, we linearly interpolate the book value over the quarter on a weekly basis. In untabulated results we find that all results in the paper are nearly identical when we use the distribution over asset changes instead of over equity returns. This occurs because the variation in market value of asset changes (as we measure it) is overwhelmingly driven by variation in equity value changes, as the variation in equity returns dominates variation in changes in balance sheet leverage ratios.

4.5.4. Examining Recessionary Periods Separately. Finally, we examine whether the results are a general recessionary effect or specific to only one of the two recessionary periods in our sample. To examine this, we re-run the analyses including only one of the recessionary periods at a time, while excluding the other. In untabulated results, we find that our results hold in both recessionary periods.

\section{Summary}

Bank regulators are concerned with excessive risk-taking by individual banks and with the contribution of individual banks to the risk of the financial system as a whole. An important unresolved issue is the extent to which bank transparency plays a role in mitigating or exacerbating such risk concerns. A key source of bank transparency is publicly disclosed financial reports that provide bank-specific information to investors and regulators seeking to understand a bank's fundamentals in order to guide investment decisions, discipline risk-taking, and enhance stability. Accounting policy choices can therefore potentially affect bank risk by impacting bank transparency. In addition to this transparency role, accounting policy can affect bank stability through its influence over the accounting numbers as quantitative inputs into numerical calculations of regulatory covenant measures such as capital ratios and leverage ratios that banks must continually maintain (e.g., Beatty and Liao [2011, 2014]).

In this paper, we investigate relations between banks' accounting policy choices and both individual bank risk and risk codependence among banks. We capture cross-bank variation in accounting policy choices by 
estimating the extent to which individual banks delay expected loan loss recognition in current provisions $(D E L R)$. We investigate the extent to which DELR is associated with greater vulnerability of banks to three distinct dimensions of risk: (1) stock market liquidity risk, (2) downside tail risk of individual banks, and (3) codependence of downside tail risk among banks.

We hypothesize that DELR is a manifestation of opportunistic loan provisioning behavior that results in reduced bank transparency. Consistent with our hypothesis, we find that DELR is associated with higher stock market illiquidity, as well as higher correlations between bank-level illiquidity and aggregate banking sector illiquidity and returns during recessions (i.e., liquidity risk). Higher illiquidity levels and liquidity risk associated with lower transparency increase equity financing costs and decreased transparency can enhance opportunities for banks to engage in risk shifting. Our liquidity risk results also have implications for systemic risk. Increased comovement between bank-level illiquidity and banking sector illiquidity and returns suggests that high $D E L R$ banks as a group will simultaneously face elevated financing frictions when the banking sector is experiencing distress that impede the group's access to new capital infusions.

To investigate downside risk vulnerability, we examine the association between DELR and the lower tail of the distribution over a bank's (the banking system's) equity returns. We find that during recessions DELR is associated with significantly higher risk of individual banks suffering severe drops in their equity values, where this association is significantly stronger for banks with low capital levels. Consistent with increased systemic risk, we find that DELR is associated with significantly higher codependence between the downside risk of an individual bank and the downside risk of the aggregate banking sector. We theorize that downside risk vulnerability at the individual bank level can translate into systemic risk by virtue of $D E L R$ creating a common source of risk vulnerability across high DELR banks simultaneously, which leads to risk codependence among banks and systemic effects from banks acting as part of a herd. 
DELAYED LOSS RECOGNITION AND THE RISK PROFILE OF BANKS

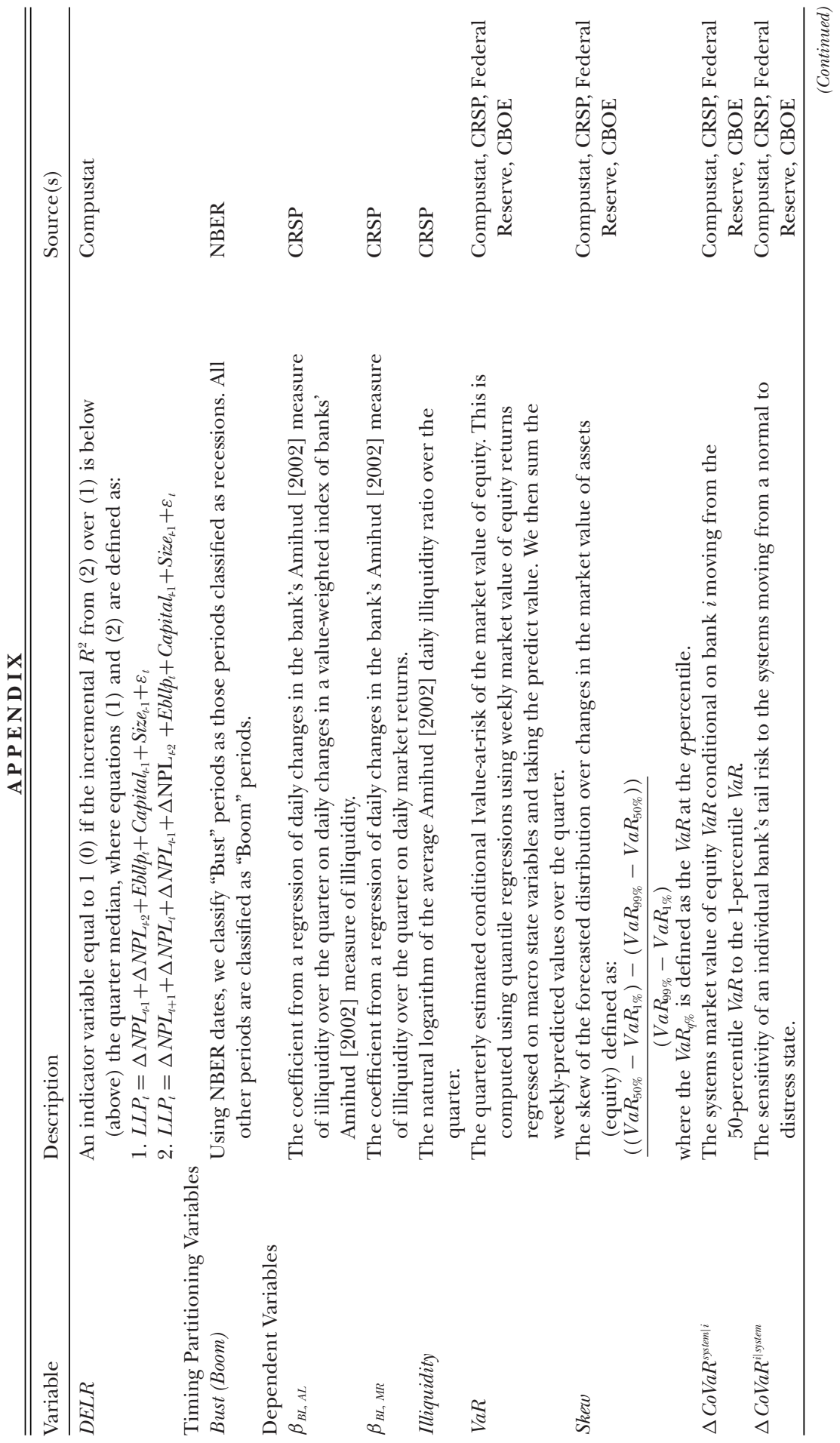




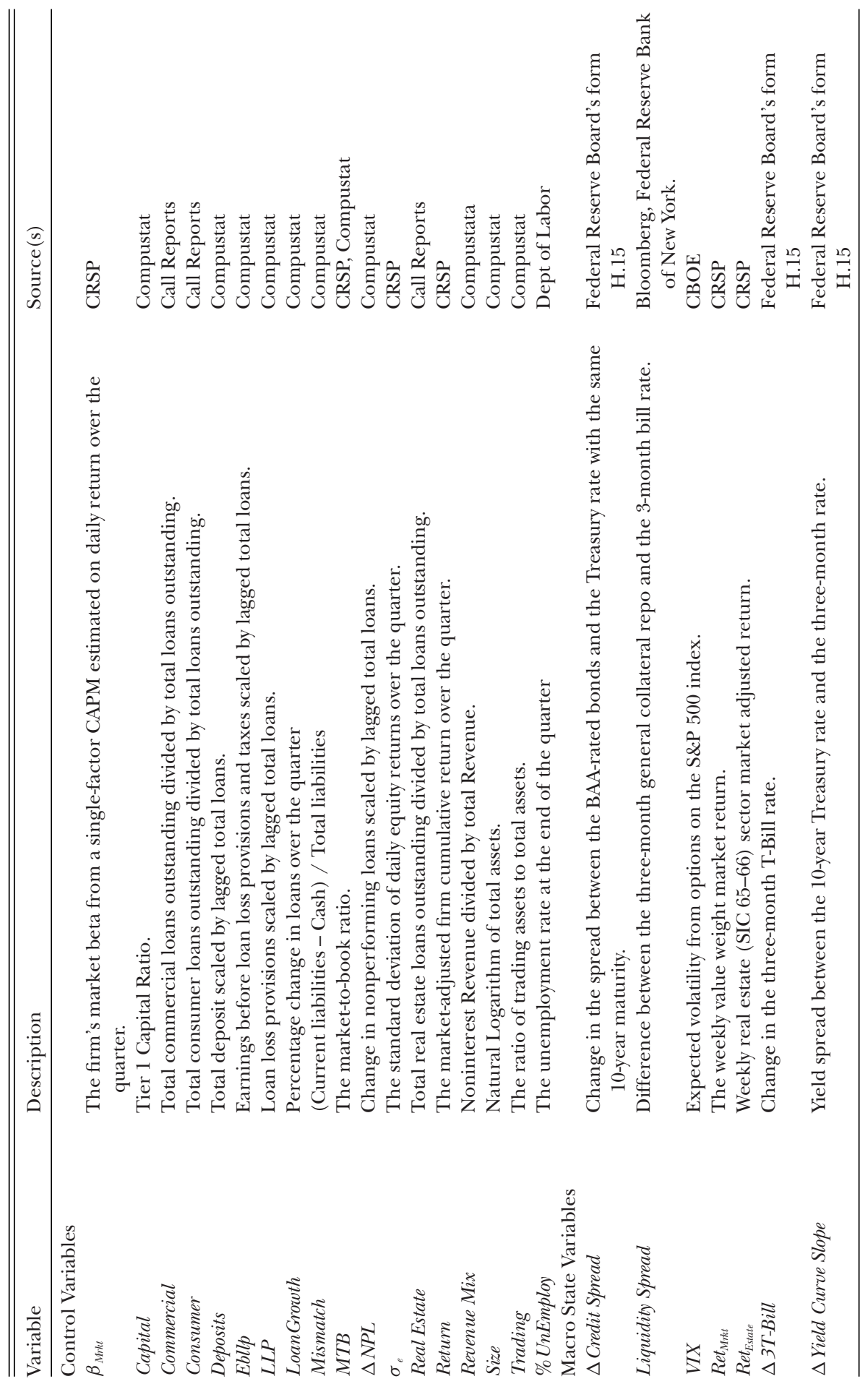




\section{REFERENCES}

ACHARYA, V., AND L. PEDERSEN. "Asset Pricing with Liquidity Risk.” Journal of Financial Economics 77 (2005): 375-410.

Acharya, V.; L. Pederson; T. Philippon; And M. Richardson. "Measuring Systemic Risk." Working paper, 2010.

Adrian, T., AND M. BrunnermeIER. CoVaR, Fed Reserve Bank of New York Staff Reports, 2011.

Afonso, G. A. K., AND A. SchoAr. "Stressed, Not Frozen: The Federal Funds Market in the Financial Crisis." Journal of Finance 66 (2011): 1109-39.

Ahmed, A.; C. TAKedA; AND S. Thomas. "Bank Loan Loss Provisions: A Reexamination of Capital Management, Earnings Management and Signaling Effects." Journal of Accounting and Economics 28 (1999): 1-25.

AmIHUD, Y. "Illiquidity and Stock Returns: Cross-Section and Time-Series Effects." Journal of Financial Markets 5 (2002): 31-56.

Aminud, Y; H. Mendelson; AND L. Pedersen. "Liquidity and Asset Prices." Foundations and Trends in Finance 1 (2005): 269-364.

BeAtTy, A.; S. Chamberlain; AND J. Magliolo. "Managing Financial Reports of Commercial Banks: The Influence of Taxes, Regulatory Capital, and Earnings." Journal of Accounting Research 33 (1995): 231-61.

BeATTY, A., AND S. LiaO. "Regulatory Capital Ratios, Loan Loss Provisioning and ProCyclicality." Journal of Accounting and Economics 52 (2011): 1-20.

BEATTy, A., AND S. LiaO. "Financial Accounting in the Banking Industry: A Review of the Empirical Literature." Journal of Accounting and Economics 58 (2014): 330-83.

Berger, A. N., And C. Bouwman. "How Does Capital Affect Bank Performance During Financial Crises?" Journal of Financial Economics 109 (2013): 146-76.

Berger, A. N.; R. DeYoung; M. J. Flannery; D. K. LeE; and Ö. Öztekin. "How Do Large Banking Organizations Manage Their Capital Ratios?" Journal of Financial Services Research 34 (2008): 123-49.

BERNANKe, B., AND C. LOWN. "The Credit Crunch.” Brooking Papers on Economic Activity 2 (1991): 205-47.

Bisias, D.; M. FloOd; A. Lo; And S. VAlavanis. "A Survey of Systemic Risk Analytics.” Working Paper 0001, Office of Financial Research, 2012.

BLuM, J. "Subordinated Debt, Market Discipline, and Banks' Risk Taking." Journal of Banking Finance 26 (2002): 1427-41.

Bolton, P., AND X. FreiXAs. "Corporate Finance and the Monetary Transmission Mechanism." Review of Financial Studies 19 (2006): 829-70.

BOYD, J., AND E. PRESCOTT. "Financial Intermediary-Coalitions." Journal of Economic Theory 38 (1986): 211-32.

Brunnermeier, M. K.; A. Crockett; C. Goodhart; A. Persaud; And H. Shin. "The Fundamental Principles of Financial Regulation." Geneva, London: International Center for Monetary and Banking Studies Centre for Economic Policy Research, 2009.

Brunnermeier, M. K.; G. DONG; AND D. PAlia. "Banks' Non-Interest Income and Systemic Risk.” Working paper, Princeton University, 2012.

Brunnermeier, M. K., AND L. H. Pedersen. "Market Liquidity and Funding Liquidity." Review of Financial Studies 22 (2009): 2201-38.

Bushman, R.; B. Hendricks; AND C. Williams. "The Effect of Bank Competition on Accounting Choices, Operational Decisions and Bank Stability: A Text Based Analysis.” Working paper, UNC and Michigan, 2014.

Bushman, R.; J. Piotroski; AND A. Smith. "What Determines Corporate Transparency?" Journal of Accounting Research 42 (2004): 207-52.

Bushman, R., AND A. SMITH. "Financial Accounting Information and Corporate Governance." Journal of Accounting and Economics 32 (2001): 237-333.

Bushman, R., AND A. SMITH. "Transparency, Financial Accounting Information, and Corporate Governance." Economic Policy Review 9 (2003): 65-87. 
Bushman, R., AND C. Williams. "Accounting Discretion, Loan Loss Provisioning, and Discipline of Banks' Risk-Taking.” Journal of Accounting and Economics 54 (2012): 1-18.

Chen, Y., AND I. HASAN. "The Transparency of the Banking System and the Efficiency of Information-Based Bank Runs.” Journal of Financial Intermediation 15 (2006): 308-32.

Cohen, L. J.; M. M. Cornett; A. J. Marcus; And H. Tehranian. "Bank Earnings Management and Tail Risk during the Financial Crisis." Journal of Money, Credit, and Banking 46 (2014): 171-97.

Cordella, T., AND E.L. Yeyati. "Public Disclosure and Bank Failures.” Discussion paper No. 1886, CEPR, 1998.

DANG, T.; G. GORTON; B. Holmstrom; AND G. ORdOnEZ. "Banks as Secret Keepers.” Working paper, Columbia University, 2014.

DeYoung, R. "Management Quality and X-Efficiency in National Banks." Journal of Financial Services Research 13 (1998): 5-22.

Diamond, D. W. "Financial Intermediation and Delegated Monitoring." Review of Economic Studies 51 (1984): 393-414.

Dou, Y.; S. G. RYAN; AND Y. Zou. "The Effects of Credit Competition on Banks' Loan Loss Provision Timeliness.” Working paper, NYU, 2014.

DuChIn, R., AND D. SosyurA. "Safer Ratios, Riskier Portfolios: Banks' Response to Government Aid." Journal of Financial Economics 113 (2014): 1-28.

Dugan, J. "Loan Loss Provisioning and Pro-Cyclicality." Remarks by John C. Dugan, Comptroller of the Currency, before the Institute of International Bankers, March 2, 2009.

Financial Stability Forum. "Report of the Financial Stability Forum on Addressing Procyclicality in the Financial System." April 2, 2009. Available at http://www.financialstabilityboard.org/publications/r_0904a.pdf.

FlAnNERY, M. "The Faces of "Market Discipline." Journal of Financial Services Research 20(2/3) (2001): 107-19.

FlanNery, M. J.; S. H. Kwan; AND M. Nimalendran. "Market Evidence on the Opaqueness of Banking Firms' Assets.” Journal of Financial Economics 71 (2004): 419-60.

Flannery, M.; S. H. KWAN; AND M. Nimalendran. "The 2007-2009 Financial Crisis and Bank Opaqueness.” Journal of Financial Intermediation 22 (2013): 55-84.

Foos, D.; L. NORDEN; AND M. WEBER. "Loan Growth and Riskiness of Banks.” Journal of Banking and Finance 34 (2010): 2929-40.

GAllemore, J. “Does Bank Opacity Enable Regulatory Forbearance?” Working paper, Chicago Booth, 2013.

Goldsmith-Pinkham, P., AND T. Yorulmazer. "Liquidity, Bank Runs and Bailouts: Spillover Effects During the Northern Rock Episode." Journal of Financial Services Research 37(2-3) (2010): 83-98.

GOLDSTEIN, I., AND Y. LEITNER. "Stress Tests and Information Disclosure.” Working paper, University of Pennsylvania, 2013.

GOldSTEIN, I., AND H. SAPRA. "Should Banks' Stress Test Results Be Disclosed? An Analysis of the Costs and Benefits." Foundations and Trends in Finance 8(1) (2013): 1-54.

GORTON, G. "The Development of Opacity in U.S. Banking." NBER Working Paper No. w19540, 2013.

Gorton, G., AND L. HuAng. "Bank Panics and the Endogeneity of Central Banking," Journal of Monetary Economics 53 (2006): 1613-29.

GrANJA, J. "The Relation Between Bank Resolutions and Information Environment: Evidence from the Auctions for Failed Banks." Journal of Accounting Research 51 (2013): 1031-70.

GRANJA, J. "Disclosure Regulation in Commercial Banking: Lessons from the National Banking Era." Working paper, MIT, 2014.

GraY, D., AND A. A. JobST "Tail Dependence Measures of Systemic Risk Using Equity Options Data Implications for Financial Stability.” Working paper, International Monetary Fund (IMF), 2009.

GRAY, D. F.; R. C. MERTON; AND Z. BodIE. "New Framework for Measuring and Managing Financial Risk and Financial Stability.” Working Paper No. 09-015, Harvard Business School, 2008. 
Hameed, A.; W. KAng; AND W. Viswanathan. "Stock Market Declines and Liquidity." Journal of Finance 65 (2010): 257-93.

HANSEN, L. "Challenges in Identifying and Measuring Systemic Risk," in Risk Topography: Systemic Risk and Macro Modeling, edited by M. K. Brunnermeier and A. Krishnamurthy. Chicago, IL: University of Chicago Press, 2014: 15-30.

Hanson, S.; A. KASHYAP; AND J. STEIN. "A Macroprudential Approach to Financial Regulation." Journal of Economic Perspectives 25 (2011): 3-28.

HuAnG, R., AND L. RATNOvsKI. "The Dark Side of Bank Wholesale Funding." Journal of Financial Intermediation 20 (2011): 248-63.

Hutton, A.; A. J. Marcus; And H. Tehranian. "Opaque Financial Reports, R-square, and Crash Risk.” Journal of Financial Economics 94 (2009): 67-86.

JIN, L., AND S. C. MYERS. "R ${ }^{2}$ Around the World: New Theory and New Tests." Journal of Financial Economics 79 (2006): 257-92.

KASHYAP, A., AND J. STEIN. "The Impact of Monetary Policy on Bank Balance Sheets." CarnegieRochester Conference Series on Public Policy 42 (1995): 151-95.

KASHYAP, A., AND J. STEIN. "What Do a Million Observations on Banks Say About the Transmission of Monetary Policy?" The American Economic Review 90 (2000): 407-28.

LAEvEN, L. "Corporate Governance: What's Special About Banks?" Annual Review of Financial Economics 5 (2013): 63-92.

Laeven, L., AND G. MajNONI. "Loan Loss Provisioning and Economic Slowdowns: Too much, Too Late?" Journal of Financial Intermediation 12 (2003): 178-97.

LANG, M., AND M. MAFFETT. "Transparency and Liquidity Uncertainty in Crisis Periods." Journal of Accounting and Economics 52 (2011): 101-25.

LOU, X., AND R. SADKA. "Liquidity Level or Liquidity Risk? Evidence from the Financial Crisis." Financial Analysts Journal 67 (2011): 51-62.

Mehran, H.; V. ACHARYa; AND A. ThaKor. "Caught Between Scylla and Charybdis?” Regulating Bank Leverage When There Is Rent Seeking and Risk Shifting. ECGI Finance Working Paper No. 365/2013, 2013.

Morgan, D. P. "Rating Banks: Risk and Uncertainty in an Opaque Industry." American Economic Review 2002 (2002): 874-88.

MORRIS, S., AND H. S. SHIN. "The Social Value of Public Information." American Economic Review 92 (2002): 1521-34.

MorRison, A. D., AND L. White. "Reputational Contagion and Optimal Regulatory Forbearance." Journal of Financial Economics 110 (2013): 642-58.

NAES, R.; J. A. SkJEltorP; AND B. A. ØDEgaARD. "Stock Market Liquidity and the Business Cycle." The Journal of Finance 66 (2011): 139-76.

Nichols, D.; J. WAHLEN; AND M. Wieland. "Publicly Traded Versus Privately Held: Implications for Bank Profitability, Growth Risk, and Accounting Conservatism." Review of Accounting Studies 14 (2009): 88-122.

PÁSTOR, L., AND R. STAMBAUgh. "Liquidity Risk and Expected Stock Returns." Journal of Political Economy 111 (2003): 642-85.

RATNOVSKI, L. "Liquidity and Transparency in Bank Risk Management.” Journal of Financial Intermediation 22 (2013): 422-39.

Rochet, J. "Capital Requirements and the Behavior of Commercial Banks." European Economic Review 36 (1992): 1137-70.

Rochet, J.-C. "Prudential Policy." Monetary and Economic Studies (Special Edition) October (2005): 93-119.

SHIN, H. S. "Reflections on Northern Rock: The Bank Run That Heralded the Global Financial Crisis, Journal Econonomic Perspectives 23 (2009): 101-20.

StEPHANOU, C. "Rethinking Market Discipline in Banking: Lessons from the Financial Crisis," Policy Research Working Paper 5227, The World Bank, 2010.

Van den Heuvel, S. "The Bank Capital Channel of Monetary Policy." Working Paper, Federal Reserve Board of Governors, 2009.

VAYANOS, D. "Flight to Quality, Flight to Liquidity, and the Pricing of Risk." Working paper, The National Bureau of Economic Research, 2004. 